Portland State University

PDXScholar

6-1-1967

\title{
The use of self-determination and confidentiality in casework and group work practice: an exploratory study
}

\author{
George A. Fisher \\ Portland State University \\ James M. Hanson \\ Portland State University \\ Frances Peterson \\ Portland State University \\ Helen Phillips \\ Portland State University
}

Follow this and additional works at: https://pdxscholar.library.pdx.edu/open_access_etds

Part of the Social Work Commons

Let us know how access to this document benefits you.

\section{Recommended Citation}

Fisher, George A.; Hanson, James M.; Peterson, Frances; and Phillips, Helen, "The use of selfdetermination and confidentiality in casework and group work practice: an exploratory study" (1967). Dissertations and Theses. Paper 229.

https://doi.org/10.15760/etd.229

This Thesis is brought to you for free and open access. It has been accepted for inclusion in Dissertations and Theses by an authorized administrator of PDXScholar. Please contact us if we can make this document more accessible: pdxscholar@pdx.edu. 
GEORGE A. FISHER et al. for the MASTER in SOCIAL WORK (Name) (Degree) (Major)

presented on May 11, 1967

(Date)

Title: THE USE OF SELF-DETERMINATION AND CONFIDENT -

IALITY IN CASEWORK AND GROUP WORK PRACTICE: AN

\section{EXPLORATORY STUDY}

Abstract approved:

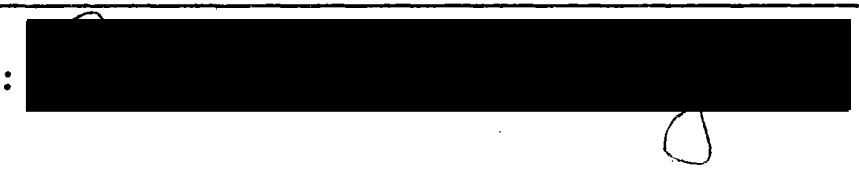

This study is the seventh in a series begun in 1957 to relate social work theory to general systems theory. The purpose of this study was to assess, through the judgment of professional social workers, the use of the two concepts, self-determination and confidentiality, in casework and social group work situations.

The two concepts were operationalized by construction of five practice principles for each concept. An instrument was developed in which a critical hypothetical situation exemplified each principle for both methods with a forced choice of four actions evidencing the degree of self-determination and confidentiality. Forty randomly selected trained social workers in the Portland area answered the questionnaire. Three propositions were tested. The first predicted that workers' judgments of the use of the two concepts would be 
significantly influenced by the unit of treatment. The second predicted that there would be a higher correlation on self-determination between casework and group work situations than on confidentiality between the two methods. The third predicted that five variables would be significantly related to differential judgments of workers of the two concepts in both methods.

\section{Findings:}

Proposition I was partially substantiated. The unit of treatment was significant for the use of self-determination, but not for the use of confidentiality.

Proposition II was not substantiated. Evidence showed, however, that the exact opposite of this proposition had occurred. There was a significantly higher correlation on confidentiality between the two methods than for self-determination.

Among the five variables selected for testing, group work experience proved to be statistically significant in the use of confidentiality in casework situations. The variance in the scores of those respondents having group work experience was over twice as large as those respondents having no group work experience in workers' judgments of the use of confidentiality in casework situations. In addition, years of social work experience showed a significant positive correlation in the use of self-determination in casework situations. There was no 
statistical significance as far as professional education in group work method, other types of training in the two methods, and preference for either casework or group work.

Though not statistically significant, it was found that those respondents with graduate education in group work showed more variance in their judgments compared with those respondents without such education, indicating that education in more than one method broadens the perceptual set of the worker but that actual experience in group work is more significant than is academic education. When years of social work experience were compared, it was found that more selfdetermination was allowed by those respondents with more years of experience, perhaps indicating that increased experience increases the personal security of the worker.

The respondents' reasons for their choice of actions indicated that they were largely guided by practice principles relating to each concept but there was an overlap among these principles. The data also showed that other concepts such as the social work relationship and the worker's responsibility to society guided some workers' choices of action.

The significance of this study is that it provided eclectic definitions of the two concepts from which practice principles were operationalized, thereby contributing to theory building; illustrated that 
perception theory can be used for research in social work practice; identified areas for curriculum planning and staff development; and pointed to areas for future research. 
THE USE OF SELF-DETERMINATION AND CONFIDENTIALITY IN CASEWORK AND GROUP WORK PRACTICE:

AN EXPLORATORY STUDY

by

\author{
George A Fisher \\ James $M$ Hanson \\ Frances Peterson \\ Helen Phillips
}

\title{
A GROUP THESIS
}

\author{
submitted to \\ Portland State College
}

\author{
in partial fulfillment of \\ the requirements for the \\ degree of \\ Master of Social Work \\ June 1967
}


APPROVED

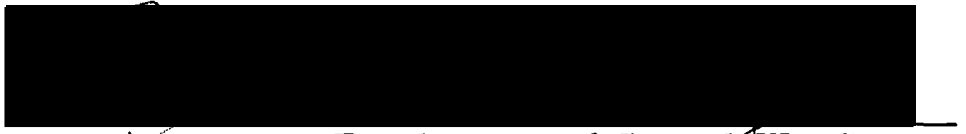

Associate Professor of SociałW Work

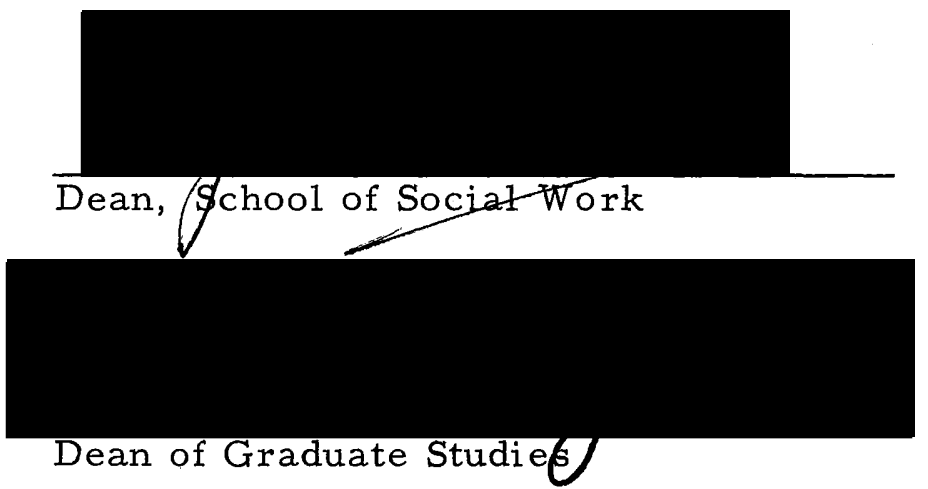

Date thesis is presented May 11, 1967

Typed by Jewell Asay for George A. Fisher, et al. 


\section{ACK NOW LEDGMENT}

The thesis committee wishes to express their appreciation to Dr. Horace Manning, Assistant Professor, Department of Psychology, Portland State College, for his contributions to this project. 
TABLE OF CONTENTS

I . INTRODUCTION

The Problem and its Significance

The Review of Studies

II . THEORETICAL CONSIDERATIONS

III . FORMULATION OF HYPOTHESES

Proposition I

Proposition II

Proposition III

IV. THE RESEARCH PROCEDURE

Selection of the Sample

Description of the Sample

Source of Data

Plan for Analysis of Data

V. STATISTICAL AND DESCRIPTIVE ANALYSIS OF DATA

Proposition I

Proposition II

Proposition III

Analysis of Content

VI: FINDINGS AND CONCLUSIONS

Propositions

Content Analysis

90

Implications of the Study

93

Limitations of the Study 


\section{LIST OF TABLES}

I. Description of the Sample 33

II. Professional Education in Group Work 52

III. Other Training in Group Work $\quad 55$

IV. Other Training in Casework $\quad 57$

V. Experience with Groups 63

VI. Práctice Principle l: Self-Determination Casework 65

VII. Practice Principle 1: Self-Determination Group Work 6.6

VII I. Practice Principle 2: Self Determination Casework 67

IX . Practice Principle 2: Self Determination Group Work 68

X. Practice Principle 3: Self Determination Casework 6.9

XI . Practice Principle 3: Self Determination Group Work 70

XII. Practice Principle 4: Self Determination Casework 71

XIII. Practice Principle 4: Self Determination Group Work 72

XIV. Practice Principle 5: Self Determination Casework 73

XV. Practice Principle 5: Self Determination Group Work 74

$\begin{array}{lll}\text { XVI. Practice Principle 1: Confidentiality Casework } & 75\end{array}$

XVII. Practice Principle 1: Confidentiality Group Work 76

XVIII. Practice Principle 2: Confidentiality Casework $\quad 77$

XIX. Practice Principle 2: Confidentiality Group Work 78

XX. Practice Principle 3: Confidentiality Casework 79

XXI. Practice Principle 3: Confidentiality Group Work 80

XXII. Practice Principle 4: Confidentiality Casework 81 
LIST OF TABLES (Continued)

XXIII. Practice Principle 4: Confidentiality Group Work

XXIV. Practice Principle 5: Confidentiality Casework

XXV. Practice Principle 5: Confidentiality Group Work 


\section{THE USE OF SELF-DETERMINATION AND CONFIDENTIALITY IN CASEWORK AND GROUP WORK PRACTICE: \\ AN EXPLORATORY STUDY}

\section{CHAPTER I}

\section{INTRODUCTION}

\section{The Problem and Its Significance}

During the past ten years, attempts have been made to develop a unified theory of social work practice. The stimulation for such a theory evolved from both the beliefs of the general systems theorists as well as the demands of social work practice for a more integrated approach to method since social workers are expected to have some competence in work with individuals, families, and various peer groups. If a unified theory of social work practice is to be built, then the parts: casework, group work, community organization, and administration must be examined for their use of overlapping referents."

The purpose of this current exploratory study is to assess, through the judgments of professional social workers, the use of two concepts, self-determination and confidentiality, in casework and social group work situations. It has been as sumed by this study group that self-determination and confidentiality are overlapping referrents in casework and group work practice. The 
community organization and administration methods of social work have been omitted from this study in order to limit the focus to the two methods of social work practice which provide direct service to clients. Subsequent studies may focus on examining the use of these two concepts or other overlapping referents in community organization and administration methods.

It is recognized that not all social workers believe that a unified theory of social work practice exists or that the profession should be seeking to establish such a theory. Sallie Churchill (1966) recently suggested that specialization was a prerequisite for professionalism and asked whether the attempt to locate and teach a general theory of social work was compatible with social work's current struggle for professional recognition. This is a pertinent question and merits at least an attempted answer. This study group, borrowing from the medical profession, has taken the position that social workers should be trained first as general practitioners and that specialization should follow.

\section{The Review of Studies}

This study is the seventh in a series which began under the guidance of Dr. Gordon Hearn while he was teaching in the School of Social Welfare at the University of California at Berkeley in 1957. Dr. Hearn subsequently accepted the position as Dean of 
the School of Social Work at Portland State College, and this series was resumed at Portland State College under the guidance of $\mathrm{Dr}$. Frank Miles. Dr. Florence Clemenger joined the faculty of Portland State College in 1.965 and is the advisor of this current study.

This series of studies has been based on general systems theory as postulated by Dr. Hearn (1958) in his monograph entitled Theory Building in Social Work. It is his belief that there should be a general theory of social work practice, and that research should be undertaken and continued toward the development of such a theory. This is not a new suggestion. It appeared as long ago as 1929 when the American Association of Social Workers published a report, quoted in part by Kendall (1959), which pointed out the need for research to show that there was a body of knowledge which was fundamental to all methods of social work. Perhaps due to the demands made upon social workers during the depression of 1929 and later by the Second World War, the recommendation of 1929 was not followed in social work.

Since the Second World War, there has been an increasing interest in the establishment of a general theory to encompass the knowledge of disciplines other than social work. Bertalanffy (1962) became dissatisfied with the study of biology as a discipline which sought to reduce organisms into parts and partial processes. He believed that they should be studied as organized things. Using 
physical chemistry, kinetics, and thermodynamics, he evolved a theory of open systems and steady states which he felt might later be expanded into a general systems theory which would be applicableto all sciences, including the social sciences.

Ackoff (1963) supported Bertalanffy's desire to unify science and increase communication between its various disciplines, but felt that this unification could not be accomplished with Bertalanffy's method which Ackoff felt was based more on empirical reasoning than on quantitative measurements. Ackoff favored approaching unification of science through interdisciplinary research, using controlled inquiry to gain an ever increasing body of knowledge. To Ackoff, the unification is in the method and activity of the inquiry, not in its resultant concepts, symbols, and laws.

McBroom (1956) noted that biology had identified periods of high imprintibility in organisms which provide opportunity for repatterning. She suggests that similar periods might be identified in the human organism such as the role transition periods of birth, weaning, adolescence, and marriage. McBroom felt that the science of human behavior has lagged behind the physical sciences and advocated research to narrow this gap. If stages of high imprintibility could be identified in man and it could be established that these stages correspond to those stages in 
biological organisms this would be a contribution toward general systems theory.

Hearn (1958) has been among the leaders of the renewed interest in establishing a general theory of social work practice; and the work of the research groups which began this series under his direction at the School of Social Welfare, University of California at Berkeley, merits consideration.

The first research group (Carlson et al., 1957) attempted to lay a foundation for the series by providing a philosophical base for social work. The philosophical statement said that social workers help their fellow man because man is a thinking, knowing being who has mastered the environment and guides the destiny of civilization or, more briefly, social workers help man because he is man.

There were dissenting statements which felt that the philosophical statement should have included social work's values, man's divinity, and the limit to man's ability to know.

The 1958 research group (Cutler et al. ) reviewed social work literature to determine how the word "generic" had been used in respect to social work practice methods. They found that some social work concepts such as acceptance, relationship, and diagnostic problem-solving had been thought of as generic to casework, generic to group work, and generic to community organization; but none of these concepts had been used in a way which would indicate 
that the user had felt these concepts were generic to all methods of social work practice.

The 1960 research group (Brill et al. ) attempted to establish that social workers reacted in similar ways regardless of the method that was being employed. This group was not able to show a similarity which was statistically significant and felt this failure was due to the use of records for data. They found it difficult to extract data from records because of difference in the amount of detail which was included by some workers but omitted by others.

The goal of the 1962 research group (Bolter et al. ) was to construct two models to illustrate that there is a common basis upon which to describe human relationships. This group did not include statistical research in their thesis but felt that their models could serve as useful guides to a practitioner but that no model could substitute for the worker's judgment in individual situations. The model used by the current study group is a simplification of one of the models which was constructed by the 1962 research group.

The first project in this series to be done at Portland State College School of Social Work (DeCristoforo et al. , 1965) attempted to relate three methods of social work practice: casework, group work, and community organization to the general systems theory by making statistical comparisons of the reactions of 
professional social workers to 427 social work concepts. This study did not produce significant similarities. It was felt that the use of phrases provided the respondents with cues as to the response. This study did furnish a reference base for subsequent studies. The following research group (Armstrong et al. , 1966) tried to avoid the error of providing cues by using action words alone as concepts. A questionnaire was formulated and sent to professional social workers requesting them to respond as to the clarity of the word, how frequently it was used in their practice, and how important it was felt to be to their practice. This study found that professional social workers responded in a significantly similar manner to 66 percent of the concepts on the questionnaire and felt that they had made a beginning step toward a general theory of social work practice.

This current study group reviewed professional publications for additional studies which have attempted to establish a general theory of social work practice but none were found.

In this first chapter, we have briefly stated the problem with which this study is concerned and our belief that it is a pertinent problem for study in the profession at this time. However, we recognize that this belief is not shared by the entire profession. We have reviewed the previous studies which have been concerned with the establishment of a general theory of social work practice. 
The chapter that follows will discuss the theoretical considerations basic to this study. 


\section{THEORETICAL CONSIDERATIONS}

In view of the purpose of this study, the concepts of selfdetermination and confidentiality were examined theoretically and for their use in casework and group work practice. We will discuss this examination by looking at each concept individually in regard to its historical development and its appearance in current social work literature. We shall begin with the concept of selfdetermination.

Felix Biestek (1951) made a detailed study of the concept of self-determination as it appeared in the literature from 1921 to 1950. He found that the term itself was not used during the 1920's but that, during that decade, there was some recognition of the principle in the use of such terms as client participation, client responsibility for planning, client self-help, client self-direction, and client self-expression. Biestek felt that there was not general agreement about the degree of self-determination that the se early witers were proposing.

His studies showed that from 1931 to 1940 the term selfdetermination became quite common in social work literature and was considered essential to the establishment of a meaningful worker-client relationship. In the decade from 1941 to 1950 , he 
found that self-determination was advocated to help the client see the different choices that were available to him, to evaluate realistically the possibilities of each, and arrive at a sound decision. The social worker's task was to assist the client to do this and to lend support to the client's decision. Self-determination was considered important because it worked in individual problemsolving and also because of the value placed upon individual freedom by a democratic society. In this later period, there was more agreement upon the underlying philosophy but; even so, Biestek felt that there were still differing degrees of self-determination permitted. This factor resulted, in part, from differing evaluations of the client's capacity to make decisions as well as a feeling in the profession that self-determination was an idealistic theory which could be used in some agencies but was not possible in others.

The positions taken by recent authors in social work literature reflect the philosophy which was stated by Bartlett (1958) that the individual is of first importance in a democratic society. Konopka (1963) emphasized that throughout history democratic societies have been characterized by increased hope and decreased fear while tyrannical societies have brought suspicion, anger, and bitterness. If this is true of societies, it should also be true of individuals. Therefore, social workers who provide self-determination for clients will inspire hope and motivation while 
authoritarian social workers will contribute fear and withdrawal. Freidlander (1958) believed self-determination to be essential for a client to win back lost self respect. Perlman (1965) felt that man's sense of choice is what builds in him his sense of responsibility and self-worth.

Further reading concerning self-determination revealed that Perlman (1957) viewed it as an individual right but expected caseworkers to be more authoritarian when dealing with clients whose capacities were in some ways limited. Hearn (1958) believed selfdetermination to be a basic principle to all social work methods as far as was possible. Hollis (1964) called self-determination a basic value limited to what the client was able to do. Biestek (1951) saw self-determination as a right limited by client capacity. Bisno (1952) limited self-determination to the normally competent person. Hamilton (1956) felt self-determination to be a right which must not follow uncontrolled impulse. All of these authors were writing about the casework: method except Hearn who was including all social work methods.

In the group work literature, Konopka (1963) said that selfhelp was fundamental to group work but added limitations where behavior would be harmful to others or destructive to property. Trecker (1955) believed that groups can only learn to behave responsibly. when given the opportunity to behave responsibly. $\mathrm{He}$ 
saw self-determination as a right limited, as is any right, by responsibility, and believed that the worker must consciously judge the amount of responsibility that a group is capable of assuming at any one time. Wilson (1956) felt that self-determination was one of the principles of group work but looked to the worker to help the clients use it within the limits which are necessary: in relation to the welfare of the community.

There is general agreement in the literature that selfdetermination is to be considered a right of all individuals, at least in a democratic society. It is also a helping technique because helping the client to solve a problem for himself gives him increased confidence in his ability to solve additional problems as they arise. Self-determination is, however, not absolute and should be limited when it may be harmful to the individual or to the rights of others.

Turning now to the concept of confidentiality, it was found to appear in the writings of Mary Richmond (1922) who said that the social worker-client relationship was the most confidential relationship that existed. As a general rule, the courts of the United States did not agree. Alves (1959) reported that the re was an occasional court decision which was favorable to the confidentiality of information given to social workers, but the majority of such court decisions held that the information given to social 
workers by clients was not privileged communication.

In the early 1930's, the New York School of Social Work (1933) published a book intended to guide teachers of social work. This book indicated that there were mixed feelings about confidentiality at that time. It was recagnized that personal information was given by the client with the expectation of receiving help from the social worker, and that there was an implied commitment that the information would not be shared with a third person. If sharing the information with a third person was, in the judgment of the social worker, the best means of providing the help, should the worker then share the information with a third person without the client's permission or pressure the client to give permission? There was no mention of the client's right to refuse help under these conditions, and this might indicate that the emphasis was more on the worker's help to the client than on the client's help to himself. The book did not answer the question that it had posed. The answer was left to the judgment of the worker in each individual situation with the admonition that it was a point of kindness and justice not to take advantage of those whose misfortunes gave the worker the power to harm.

More recently, Joseph Alves (1959) interviewed 48 practicing social workers about their use of the concept of confidentiality. Two-thirds of his respondents based their belief in this concept 
on the individual rights of each man which exist under natural law. One-third of his respondents regarded confidentiality only as a tool to be used to gain information from a client.

Current social work Iiterature evidences less agreement about the concept of confidentiality than is shown for self-determination. Joseph Alves (1959) found that nearly all of his respondents said that the concept of confidentiality was confused and needed clarification. He felt that this stemmed from frustration due to the desire to practice confidentiality but being unable to do it because courts have required that social workers' records be brought into court and used as evidence. Alves quoted from Dean Wigmore who has written about the legal aspects of privileged communication. Dean Wigmore believed that, to be considered privileged, communication must meet four criteria which can be summarized as: (1) There must be intent that the communication will be held confidential. (2) Confidentiality must be essential to the relationship. (3) The relationship must be considered by the community as one which ought to be fostered. (4) The injury caused by disclosure of information must be greater than the benefits of such disclosure.

Alves (1959) believed that the social work relationship fulfills the requirements of the above first two points but that a public poll would probably return a negative result regarding point 
three. As to the fourth point, he believed that it would be very difficult to establish legally that the harm from any disclosure would outweigh the benefit and suggested that social workers be given more training in philosophy to equip them better to make such a determination independently. Thus, social workers would be able to promise complete confidentiality to clients limited only when the benefit to the client is outweighed by harm to others. The confidentiality of personal information is important to free communication between client and worker and this communication is essential to treatment. Perlman (1957) felt that talking brings the human experience into consciousness where it can be managed and is, therefore, a major tool in social therapy. It is important that the client talk to give information to the social worker but it is more important that the client talk to give information to himself.

Hamilton (1956) felt that confidentiality is one of the most important ethical considerations in work with individuals and with family groups but added that it should be limited when the client is ill, psychotic, or a menace to society. Weingarten (1958) called confidentiality a basic right of every person served by a social agency, but felt that the worker should evaluate each situation and use the degree of confidentiality which would most benefit the client. Group work writers were reviewed but all did not include a 
discussion of confidentiality in their writings. Slavson (1954) wrote that a therapeutic atmosphere depended upon complete freedom of communication with no barriers to the flow of thought and feeling. Konopka (1963) felt that the client could rely on confidentiality in a casework situation but that confidentiality could not be guaranteed in group work. She believed that, in group work, confidentiality could only be established by the mutual effort and agreement of all of the members of a group. Whitaker and Lieberman (1964) also felt that confidentiality in a group could only be established by agreement among the group members. Trecher (1955), Powdermaker and Frank (1953), and Wilson and Ryland (1949) were reviewed but it was not found that these authors discussed confidentiality in relation to group work practice.

The literature reviewed pointed out that there are four points in which the two concepts, self-determination and confidentiality, are essentially similar. These are: (1) Both concepts are considered to be rights of individuals in a democratic society.

(2) Both are considered to be instrumental social work values.

(3) Both are considered as techniques by which a client is helped.

(4) Both concepts have limitations; neither is considered as absolu.te.

The above evidence lends support to one of the basic assumptions of this study, that the concepts of self-determination and 
confidentiality are generic to both casework and group work practice. The following model (figure 1) illustrates this as sumption.

Model of the assumption that selfdetermination and confidentiality are generic to both casework and group work practice.

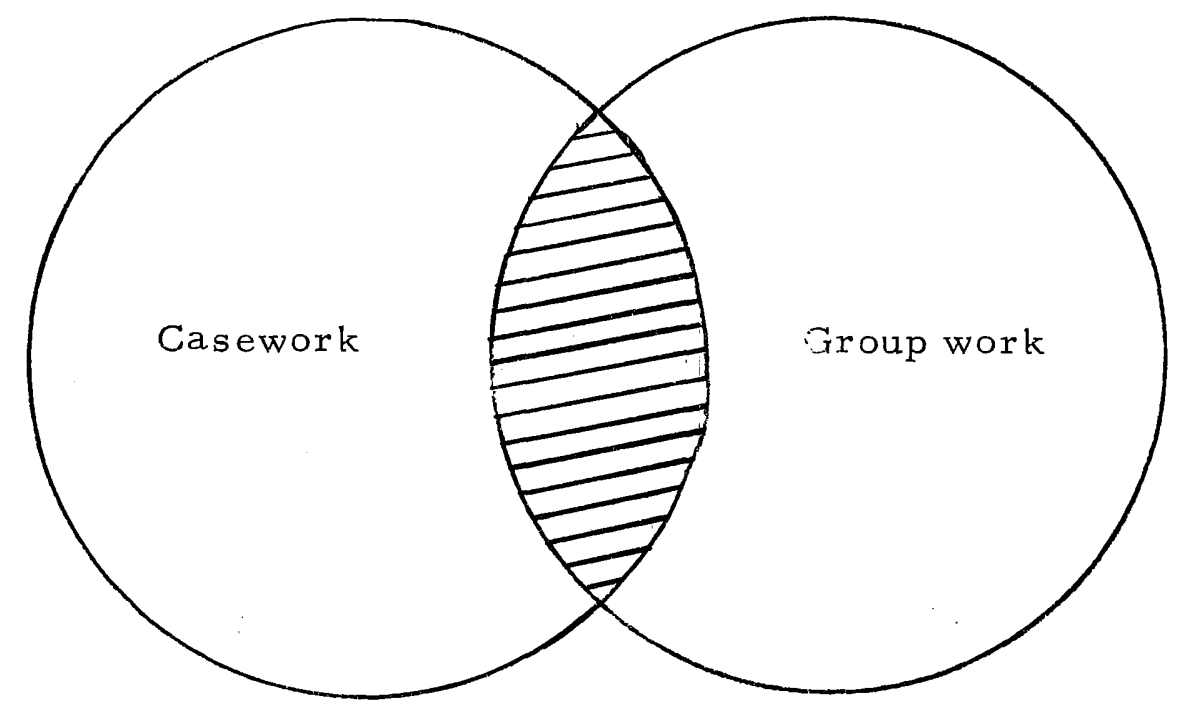

Figure 1. Self-determination and confidentiality are two overlapping referents and lie within the shaded area.

From the reading of the literature and for purposes of this study, we have eclectically defined the two concepts being studied. In ordèr to operatónalize the concepts for study, we used the method devised and used by Lydia Nolan (Greenwood, 1963) in her studies at the University of California at Berkeley. She and her research groups operationalized the abstract concepts by selecting the how, the why, and the what of the concept and writing these 
in the form of a social work practice principle or guide to action.

The first of the two concepts being studied was defined as

follows:

Self-determination in social work practice is the worker's conscious recognition of the right of the client to direct his own life, to pursue his own goals, to meet his own needs, and to determine how these needs should be met, as they are compatible with the realities of his diagnosed capacities, in relation to the rights of other persons, and within the context of society's limitations.

Although many practice principles could be written for this concept, we selected five themes as being central to the use of self-determination in practice. These are: (1) recognition of the ineffectualness of forced change, (2) restraint from imposing values, (3) guidance rather than direction, (4) awareness of client capacity, and (5) encouragement of client participation. From these central themes, the following practice principles were constructed:

1. The social worker recognizes his limitations in forcing change upon another person whose internal needs and conflicts are complex; therefore he sees his role chiefly as one of stimulating thought about alternative choices without removing responsibility from the client.

2. The social worker refrains from imposing upon clients his own values, goals, and methods of performance in order to protect the right of the clients to make their own decisions.

3. The social worker guides clients toward finding new ways to solve their problems so that clients 
may retain their self-respect and increase their confidence.

4. The social worker should be aware of a client's capacity to act for himself in order that the worker does not expect self-determination beyond that which is possible for the client.

5. The social worker encourages the fullest possible participation of the clients in the working through of their problems so that the clients may increase their ability to find more effective solutions to their needs.

The second concept being studied was defined as follows:

Confidentiality in social work practice is the restriction of personal information about the client by the social worker based on the respect for the client's right to privacy; or the ethical and purposeful release of information in order to facilitate explicit treatment goals.

The five central themes chosen with which to operationalize this concept were: (1) the establishment of a working relationship, (2) the worker's responsibility to the community, (3) the use of information given to other agencies, (4) obtaining the client's consent to request information, and (5) the privacy of the physical facilities which are used. The following practice principles were then constructed to operationalize the concept of confidentiality:

1. In order to establish basic trust between clients and worker which is necessary for a social work relationship, the worker will convey to the client by some means of verbal communication, the assurance that personal information revealed by the clients will be used only in the clients' best interests in accordance with the values and ethics of the social work profession. 
2. In order to protect the welfare of the community, social workers will purposefully advise their clients to reveal information known to them that would be useful to law enforcement agencies in performing their function of community protection.

3. In order to maintain a continuity of confidentiality for clients between various workers and agencies, social workers will release private information about their clients only to those who will respect the confidential nature of the information.

4. In order to protect the privacy and integrity of the client, a social worker will not obtain information about a client by requesting it from collateral sources without the client's knowledge and/or consent.

5. In order to insure the client's right to privacy, the physical facilities will be so arranged that the personal information about clients will be discussed only among those persons who are directly concerned with the treatment.

Since this study is concerned with the judgments of professional social workers as to the use of self-determination and confidentiality, it involves perception theory. Perception is defined by Bruner (1957) as "the categorization of an object or sensory event in terms of more or less abundant and reliable cues". (p. 46) Dember (1960) defined perception as "the organizing process of apprehending probable signification in the perceiver's immediate environment which he has found from previous experience to have furthered his purpose". (p. 3)

These definitions suggest that, as was noted by Allport, 
(1955) there is more to perception than the simple as sociation and response of an individual to a given stimulus. He believed that there exists a pre-established attitude or set which is important in determining the reaction. Solley and Murphy (1960) described perception as a process which includes: (1) the preparation or attitudinal set, (2) the expectation of what is to be perceived, (3) the physiological capacity of the perceiver, (4) the time lag required for mental testing, and (5) the consolidation of the stimulus traces.

It is of importance to be aware of the existence of the perceptual set as described by Allport as well as the first point of Solley and Murphy's description of the process of perception. Perceptual set has been defined by Dember (1960) as "a type of context provided by cognitive conditions such as interest, attitudes, needs, values, and expectations". (p. 272) Social judgments, with which this study is concerned, are described by Forgus (1966) as being based upon common configurational principles such as common fate, radius of action, similarity, proximity and others. These influence an individual's ability to perceive by making him more or less aware of certain attributes of the stimulus complex.

The literature of perception theory indicates that perception is influenced by pre-established attitudes and that such pre-established attitudes may occur because of the education, training, and experience of an individual. It may be concluded 
from this that respondents' judgments of the use of the two concepts, self-determination and confidentiality, in casework and group work situations will be based on the cues inherent in the situation to be judged. The respondents will also be influenced by their perceptual sets which evolve from their education, training, experience, and from the values of the social work profession. However, as was suggested by Forgus (1966), individuals who are particularly trained in a given àrea may be less likely to adopt narrow sets in that area.

We will now proceed with Chapter III in which we shall develop the hypotheses which will guide the study. 


\section{FORMULATION OF HYPOTHESES}

In the light of the problem under study, the theory and findings from relevant studies, three propositions were posed for testing:

\section{Proposition I}

The workers' judgments of the use of self-determination and confidentiality will be significantly influenced by the unit of treatment. (one-to-one or group)

As operational guides, instrumental values such as selfdetermination and confidentiality present potential areas of disagreement related to variations in process between casework and group work. We therefore believe that workers will be influenced in their utilization of the concepts of self-determination and confidentiality by whether they find themselves in a casework or group work situation. We expect to find a significant difference in their scoring of the hypothetical situations between the two methods.

Basic to both practice methods is the worker-client relationship. This relationship in the one-to-one casework situation is of a different nature than within the context of a group where the worker must direct his understanding not only at individuals but at the group as a whole and interactions among group members. 
While the worker is usually able to protect his client's privacy in the casework relationship, he cannot assure it in a group where the matter of confidentiality is settled by group members themselves at a time when the is sue is meaningful and in the manner appropriate for the group. "For the therapist to introduce standards or assurances about the maintenance of confidentiality is unnecessary and will be ineffective unless concomitant developments within the group establish such standards as a part of a. group solution." (Whitaker and Lieberman, 1964, p. 210)

If client capacity is accepted as the criterion for judging the limits of client self-determination, this would seem to indicate a need for as many: and differing limitations as there are individuals with differing capacities within a group. The group worker's task becomes one of multiple diagnosis in which it is necessary to consider not only the several clients but also to appraise the effect of their interactions upon each other and the group as a whole. In a casework relationship, the worker need only be concerned with the diagnosis and capacities of a particular client. Likewise, it is more readily possible for the worker to enable a single client to identify, and pursue his primary. goals than to assist a group to work through all the interpersonal differences involved in achieving concensus and motivation toward a common purpose. 


\section{Proposition II}

The correlation of workers' judgments of self-determination between the casework and group work situations will be higher than these workers' judgments of confidentiality between the casework and group work situations.

Our review of the literature has shown more agreement among social work authors about the use of the concept of self-determiration than about the use of the concept of confidentiality. We therefore expect to find a higher correlation in responses of workers to the hypothetical situations for the concept of self-determination than for the situations utilizing the concept of confidentiality.

Both methods place heavy reliance upon self-motivation of the client and, generally speaking, use non-coercive methods of change. Self-determination is valued equally whether for the individual or group and, restricted only by client capacity, the rights of other persons, and society's limitations, holds a high priority in all social work practice.

For confidentiality, there is no universal agreement. There are no clearly defined operational rules to guide workers in all agencies in all situations. While there is general agreement about the utility of confidentiality in maintaining a therapeutic professional relationship with clients, there may be more control possible in the usual casework situation than in the group work setting. There is a difference of opinion about which information needs to be kept 
confidential. In the Alves (1959) study of practicing social workers, most of the respondents felt that not all information was confidential to the same degree. Of group work authors reviewed, only Konopka (1964), Slavson (1954), and Whitaker and Lieberman (1964) were found to discuss confidentiality. Does this reflect that while desirable in principle, confidentiality is felt to be difficult if not impossible of attainment in a group? The potential for violation of a confidence would logically appear to be in direct proportion to the number of persons in a group. Perhaps a result of these divergences of opinion within the profession is the fact that confidences divulged to the medical and legal profession are judged to be privileged communication while social work as yet lacks this protection for its clients.

\section{$\underline{\text { Proposition III }}$}

Several selected variables will be significantly related to the differential judgment by workers of the two concepts of self-determination and confidentiality in casework and group work. These are: professional education in group work method, other types of training in casework or group work method, preference for the casework or group work method, years of social work experience, and experience in work with groups.

While other factors may be considered significant, we chose to use them as descriptive of our sample rather than as variables whose statistical significance we would explore in the present study. 
Professional Education in Group Work Method

Most if not all workers will have had education in casework method; therefore casework perceptual set will form the basis for their judgments. Since group work method education has been included in the curriculum of most schools of social work only in recent years, we anticipate many of our sample may lack formal education in this method. We expect that workers who have the additional education in group work will have an expanded perceptual set, a broader base of knowledge with which to make their judgments of the hypothetical situations than workers who lack group work education.

Other Types of Training in Casework or Group Work Method

We believe that additional training other than academic education will also prove significant. This includes in-service workshops, staff development courses, certificate programs, seminars, institutes, or other relevant learning experiences such as are frequently provided by employers to increase the capabilities of staff. If group work method knowledge has been gained in this way, we believe the judgment of workers will reflect a broader perceptual set in the use of concepts in group work situations. If the additional training has been in casework method, we believe 
the worker's judgment of casework situations will reflect a broader perceptual set, and, in either case, more variance for situations utilizing that method in which the additional training has been gained. With other types of training in both methods, we expect to find more variance in scoring the hypothetical situations for both casework and group work. If a worker has had no additional training, we expect to find less variance in responses to both kinds of hypothetical situations.

Preference for Casework or Group Work. Method

A preference for the casework or group work method will, we believe, result in a differential response by the worker to the hypothetical casework and group work situations. Preference is "an attitude or an emotionalized system of ideas which predisposes one to act in a certain way under certain conditions. Attitude learning usually takes place through experiences which engender particular emotional reactions." (Ruch, 1958, p. 305) People respond favorably to experiences which have been successful or, in the language of psychology, are conditioned to prefer that method which has rewarded them. We therefore believe workers who have found group work of benefit to their clients will reflect this in their selection of group work method as a preference. Other workers who have found casework to be most beneficial in 
their agency setting, with a particular type of client, or best fitted to their own style of practice will prefer this method. There may be negative conditioning as well; if a worker has had unfavorable experience in utilization of group work method, he will undoubtedly choose the alternative method as his preference. Whichever preference is indicated, we believe this will result in more variance in judgments of the two concepts of self-determination and confidentiality for that method than for the method which is not preferred. If the respondent indicates no preference, there is likely to be less variance in his scoring of the hypothetical situations.

Years of Social Work Experience

We believe the number of years of social work experience will prove to be a significant variable in the workers' judgments of the use of the two concepts in the hypothetical situations. There are changes concerning the understanding and application of instrumental values over time. Continued research and clinical experience tend to modify previous views of particular values. We expect to find a correlation between years of experience and application of workers' judgments in scoring hypothetical situations since the respondents will probably have received their education at the same time when certain emphases predominated in social 
work education.

Experience in. Work with Groups

We expect that experience in work with groups will prove to be a significant variable in workers' judgments of the two concepts. We believe that those workers who have had group work experience will show more variance in their judgment of the situations than those without group work experience. Our rationale for this hypothesis is based on the fact that the group work experience will provide workers with a broader perceptual base, a more skilled perceptual set for use in making judgments of the hypothetical situations. 


\section{CHAPTER IV}

\section{THE RESEARCH PROCEDURE}

\section{Selection of the Sample}

The research sample consisted of 40 social workers living in the Portland area whose names were randomly selected from the 1965 National Association of Social Workers Directory. The choice was accomplished by selecting every third name and address in the directory. After 40 persons were selected, a list of 15 alternates was chosen randomly from the remaining names.

Our initial plan was to select a stratified sample that would include 20 second year social work students at Portland State College School of Social Work and 20 practitioners in the Portland area who had their master of social work degree (MSW). However, this plan was discarded after the complexities of involving second year students were considered. They were all involved in their own research projects and did not have ample time to respond to the questionnaire. In addition, their educational backgrounds were all similar as they, were all in the same courses in graduate school. Few of them had previous group work experience although all had graduate group work education. Thus, it was believed this group would be too skewed for a random sample of the available student 
population and, as a result, the focus of this study was shifted to include only practitioners with MSW degrees.

The number in the sample was retained since it comprised 35 percent of the total population of trained social workers in Portland. The sampling area was restricted to Portland since it is known that this metropolitan area contains the largest representation and concentration of social workers in the state of Oregon.

Also, this number of 40 was small enough to allow the researchers to personally deliver and pick up the schedules yet large enough to insure representation and statistical analysis. Finally, the realities of time and academic pressures on student researchers were also factors involved in the research procedure.

The procedure used to enlist the support of the respondents in answering the questionnaire was to contact them by the telephone, explain our research goals, and ask for their assistance in completing the schedule. Of the initial 40 persons randomly selected, four were unable to be located and five persons were unable to assist with the project due to previous commitments and/or conflicts with other responsibilities. It was therefore necessary to substitute nine names from our list of alternates.

It should be noted that each of the four student members had a similar set of explanations to follow when enlisting the support of participants in this study. (Please see the appendix for a copy of this explanation) 
Description of the Sample

The information taken from the face sheet provided descriptive information regarding the sample, in addition to giving us the necessary information to analyze the important variables of this study. This information is presented in the following table form for easier analysis. (A copy of the face sheet is included in the appendix)

TABLE I

DESCRIPTION OF THE SAMPLE

Years of Social Work Experience

N 40

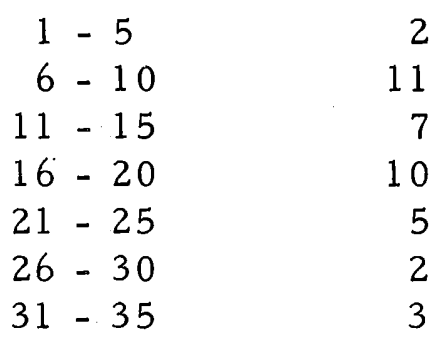

Places of Employment

N 40

Public Agencies Ser. Fam. \& Child 10

Public Schools $\quad 7$

Out-Patient Psych. Services 6

Private Agen. Ser. Families \& Ch. 6

County Public Welfare Com. 5

In-Patient Psych. Services 2

Community Planning Council 2

State Board of Health 1

Out-Patient Medical Services 1 
TABLE I: DESCRIPTION OF THE SAMPLE (continued)

Advanced Social Work Degrees

N 40

MSW

38

MSW plus 3rd year

1

BA-No: MSW, but 3rd yr. 1

Respondents Employment Positions

$\mathrm{N} 40$

Direct Service $\quad 14$

Agency Depart. Heads 12

Supervisors 6

S. W. Consultants 3

Agency Directors 3

College Professor 1

Field Work: Instructor 1

Years of Casework Experience

N 40

$\begin{array}{rr}\text { None } & 2 \\ 1-5 & 10 \\ 6-10 & 13 \\ 11-15 & 6 \\ 16-20 & 2 \\ 21-25 & 3 \\ 26-30 & 3 \\ 31-35 & 1\end{array}$


TABLE I: DESCRIPTION OF THE SAMPLE (continued)

Years of Group Work Experience

N 40

$\begin{array}{rr}\text { None } & 21 \\ 1-2 & 8 \\ 3-4 & 7 \\ 5-6 & 1 \\ 7-8 & 2 \\ 9-10 & 0 \\ 11=15 & 1\end{array}$

Years of Graduate Casework Education

N 40

$\begin{array}{rr}1 & 1 \\ 2 & 38 \\ 3 & 1\end{array}$

Years of Graduate Group Work Education

N 40

$\begin{array}{lr}\text { None } & 29 \\ 0.5 & 5 \\ 1.0 & 2 \\ 1.5 & 0 \\ 2.0 & 4\end{array}$

Other Types of Casework Training, in Years (Seminars, Institutes, In-Service Training, Staff Development, Workshops)

N 40

$\begin{array}{lr}\text { None } & 31 \\ 0.5 & 1 \\ 1.0 & 3 \\ 1.5 & 0 \\ 2.0 & 2 \\ 2.5 & 0 \\ 3.0 & 3\end{array}$


TABLE I: DESCRIPTION OF THE SAMPLE (continued)

Other Types of Group Work Training, in Years (Seminars, Institutes, In-Service Training,

Staff Development, Workshops)

N 40

$\begin{array}{lr}\text { None } & 32 \\ 0.5 & 2 \\ 1.0 & 2 \\ 1.5 & 1 \\ 2.0 & 3\end{array}$

Social Work Practice Preference

N 40

$\begin{array}{lr}\text { Casework } & 35 \\ \text { Group Work } & 3 \\ \text { None } & 2\end{array}$

It is interesting to note from Table I that the modal point for social work experience of the sample respondents was from six to ten years with a high of 11 in this category, followed closely with ten respondents who had 16 to 20 years of social work experience. Public agencies serving families and children were the most highly represented with ten of their social workers in the sample group. Public schools were second with seven respondents. Fourteen of the respondents were in direct service with clients and the second highest category represented was that of agency department heads with 12. The modal point for years of casework experience was 
from six to ten years with 13 in this category, however, slightly more than 50 percent of the respondents had from one to ten years of experience. Twenty-one of the respondents had no group work experience. Eleven of them had graduate education in group work ranging from one semester to two years. Thirty-eight had two years of graduate casework education. Finally, 35 of the respondents preferred the casework method of direct service, while three preferred the group work method.

\section{Source of Data}

The instrument developed by the group to obtain data for this study was a forced choice questionnaire that described twenty critical situations that could occur in social work practice. There were ten situations for casework and ten for group work respectively. These situations incorporated the practice principles that operationalized the two social work concepts chosen for study; self-determination and confidentiality. The situations were devised by the research members by utilizing their own field work experience before coming to graduate school and social work literature. Each critical situation exemplified one of the practice principles described in the chapter on theoretical considerations. The situations were devised to be similar for casework and group work in order to test the differential use of the concepts in the two 
types of direct service methods. Naturally, the situations were different to the extent that the treatment methods are different due to the differential number of people involved.

For the instrument, the situations were anchored under the general headings of the two core concepts but the casework and group work situations were scrambled so that the respondents would not detect basic similarities and as a result offer a patterned response.

The respondents were offered four choices and were asked to choose one as the action they would take if faced with this situation. They were also asked to state their reasons for the particular choice. Thus, a forced choice method was used that would allow for alternative courses of action.

Each choice offered represented a different degree of confidentiality and/or self-determination starting from the choice reflecting the least degree of the concept to that reflecting the greatest degree of the concept operationalized in its most complete form. These choices were devised by the group members in a manner similar to that used in formulating the practice situations. In the schedule they: were scrambled under each situation so that their order on a continuum would not be used as a guide for responding. (A copy of the schedule and directions to the respondents are included in the appendix)

The schedules were personally delivered and picked up by the 
group members, each being assigned ten schedules as their responsibility. This method of handling was decided upon to reduce the number of unreturned questionnaires one always encounters when relying on a mailing procedure. Our procedure was quite effective and was completed within a three-week period from November to December, 1966. Thus, we believe that this method, while requiring a little more effort, is much more satisfactory than mailing.

The questionnaire was pretested with a random sampling of 28 of the 38 first year graduate social work students. The use of this group for pretesting was based on their accessibility and the wish to retain the population of trained workers in the Portland area as a source for our random sample. The pretest was done during a two-hour class period graciously allotted to us by the instructor of the research class.

The pretest questionnaire was analyzed for errors and discrepancies. The critical situations and choices were made more clear and understandable as a result of the remarks of the students and their contributions were very helpful.

\section{Plan for Analysis of Data}

An overall plan for analysis of the data derived from the questionnaires was formulated prior to the completion of the 
questionnaire. This plan is outlined in the following manner.

Initially, in order to ascertain the amount of difference between the four choices in relation to each situation and to determine if they actually did offer a legitimate difference in choice, two groups of people outside of the research project were selected as raters for weighting the choices. Our first group, composed of ten of our first year graduate students at the college, were asked to rate each set of four choices on a forced choice scale of from one to seven and not to allow the total number for the four choices to exceed the numerical rating of ten. This group was provided with definitions of the concepts to use as a basis for rating the choices as given. They were asked not to consider what they would do as the social worker in question but rather to objectively analyze the four choices and assign a weight to each choice. (A sample of the instructions given to the raters is in the appendix)

In spite of these instructions, the weighting procedure was not effective as: (1) the students, generally speaking, were unable to see the differences in degree between the four choices and they assigned similar ratings to many of them, and (2) their answers were too subjective and they did not follow the directions as requested. It was necessary to have the choices weighted again. We chose as our second group of weighters three persons with MSW degrees and social work experience. Their names were 
excluded from the larger research sample. We believed that persons with more education and experience could address themselves to the required task more readily than the student group and also that they would be able to see more clearly the difference between the four choices.

However, we again encountered the same problem although on a smaller scale but enough of the choices were weighted the same to render the results invalid for our purposes. It appeared that the perceptual set of the first year social work students and of the three professional social workers who were chosen as weighters made it difficult for them to assign degrees of difference to the four choices. They tended to respond as social workers by assigning maximum weight to the choice they felt was best social work practice rather than that which reflected the greatest degree of the concepts. Therefore, the research group decided to weight the four choices themselves. We allowed ourselves the option of assigning any: weight from one through seven to each of the choices. This allowed the means of the individual weighters to shift. The mean of the four weighters was computed for each choice and used as the degree of the concept reflected by that choice. We found this particular aspect of the research project a rather difficult task ourselves.

Our statistical plan was conceived to test not only the 
statistical significance of the propositions, but to describe general characteristics of the data obtained. (Selltiz et al, 1965) These procedures would constitute measures of quantitative and probability analysis. The quantitative data would be obtained from the individual weighted scores which would be averaged for each respondent in the separate categories of casework and group work in the two concepts, self-determination and confidentiality, resulting in four mean scores for each respondent. These could be employed in a variety of different ways, appropriate to the statistical methods to be used. Several specific statistical procedures were selected as being appropriate to the study.

$\underline{\text { Proposition I }}$

The Chi Square test was chosen as a suitable analysis of frequency data. In using this procedure, it was planned to test the significance of the discrepancies between observed and expected frequencies of individual mean scores from the use of the two concepts, self-determination and confidentiality, by the two: methods, casework and group work.

\section{$\underline{\text { Proposition II }}$}

A method of determining correlation appeared to be indicated, and for this the Pearson Product Moment Correlation Coefficient 
was selected. It was planned that this procedure would be employed in determining correlation between individual respondents' mean scores in casework and group work in the use of the two concepts.

\section{$\underline{\text { Proposition III }}$}

Dealing with variables called for two different measures of statistical analysis. In testing the variable of years of social work experience, a Spearman Rank Correlation was the procedure of choice. For the remaining variables, academic education in group work, additional training in either method, preference for casework or group work, and experience with groups, the $F$ test of variance was considered appropriate. It was believed that this statistical procedure would determine the variability within the group of the effect in practice of these four variables. (Ruch et al., 1958)

A further aspect of the analysis of the data was also considered necessary as the research instrument included a section in which the respondents could make written explanations of the reasons for their choice of answers to the hypothetical social work situations. Therefore, a method of qualitative or content analysis was necessary so that the information given by the sample in this section of the questionnaires might be utilized to the fullest extent. (Selltiz et al, , 1965) 
The process of content analysis selected would involve the entire research group who would together read and study the respondents' reasons for choices of action in the hypothetical situations to determine the theme of each choice. These themes would be classified into various categories a priori. As the hypothetical situations had been constructed around the practice principles drawn from the concepts, self-determination and confidentiality, it was considered important to use the practice principle pertaining to the corresponding casework and group work situations as one of the content categories. Since it was also believed that the practice principles would not be exclusive of each other in use, it was believed possible that other practice principles might be reflected in the respondents' reason for choice. The possibility that some persons might use the concept alone as a reason, without further elaboration, was also considered as another category, i. e., client's right to self-determination (or confidentiality).

It was believed, too, that other factors might enter into the reasons for choice, such as, maintaining the casework relationship, expediency, or other conditions inherent in the hypothetical situations. 


\section{CHAPTER V}

\section{STATISTICAL AND DESCRIPTIVE ANALYSIS OF DATA}

This chapter presents a descriptive and statistical analysis of data as they relate to the three propositions posed for testing.

\section{Proposition I}

The workers' judgments of the use of self-determination and confidentiality will be significantly influenced by the unit of treatment, (one-to-one or group).

$$
\begin{aligned}
& \mathrm{H}_{1}: \mathrm{GW} \neq \mathrm{CW} \text { re: Self-determination } \\
& \mathrm{H}_{0}: \mathrm{GW}=\mathrm{CW} \text { re: Self-determination } \\
& \mathrm{H}_{1}: \mathrm{GW} \neq \mathrm{CW} \text { re: Confidentiality } \\
& \mathrm{H}_{0}: \mathrm{GW}=\mathrm{CW} \text { re: Confidentiality }
\end{aligned}
$$

It was predicted in Proposition I that we would find a significant difference between the scoring of self-determination and confidentiality for the two methods, casework and group work. The null hypothesis is that there would be no difference between the scoring of self-determination and confidentiality for the two methods. The Chi Square Median Test (Siegel, 1956) was selected to test the significance of the differences between the observed and expected frequencies of individual mean scores in the two methods, in relation to self-determination and confidentiality. The Median Test is a 
procedure of testing whether two independent groups differ in central tendency. The test was chosen since the casework and group work scores in self-determination and confidentiality were independent samples, and data provides for nominal level of measurement.

The test was applied to the data twice, once for selfdetermination in casework and group work, and once for confidentiality in the two methods. To arrange the data necessary for the Chi Square Median Test, the mean scores of the respondents from the hypothetical situations in casework and group work in selfdetermination were combined from which the median was computed, which was 5.45. The frequency of the scores was then recorded in each of the "high" or "low" cells; above or below the median value, and were dichotomized into either the casework or group work category. The level of significance used was p. 05, with one degree of freedom.

The result of the Chi Square Median Test for self-determination in casework and group work was a Chi-square value of 11.4. This Chi-square value of 11.4 is significant at the p.001 level, d.f. $=1$, $N=80$. Since p.001 is less than p. 05, the decision was to reject the null hypothesis and accept the alternate hypothesis, that there was a significant difference in the scores of self-determination between the two methods. 
$\mathrm{H}_{1}: \mathrm{GW} \neq \mathrm{CW}$ re: Self-determination, accepted.

The Chi Square Median Test was applied in a similar manner to the workers' judgments in the use of confidentiality. The median value was 5.32 . The Chi-square was found to be .25. A Chi-square value of .25 , with d.f. $=1, N=80$ was found to be significant at the p. 70 level. Since p. 7.0 is greater than p. 05, the decision was to reject the alternate hypothesis, and accept the null hypothes is that there was no significant difference between the workers'scores in judging confidentiality in casework and group work methods.

$$
\mathrm{H}_{0}: \mathrm{GW}=\mathrm{CW} \text { re: Confidentiality, accepted. }
$$

\section{Proposition II}

The correlation of workers' judgment of selfdetermination, between the casework and group work situations, will be higher than these workers' judgments of confidentiality (again between the casework and group work situations).

$$
\begin{aligned}
& \mathrm{H}_{\mathrm{I}}: \mathrm{r}_{\mathrm{sd}}>\mathrm{r}_{\mathrm{c}} \text { in } \mathrm{CW} \text { and } \mathrm{GW} \\
& \mathrm{H}_{0}: \mathrm{r}_{\mathrm{sd}}=\mathrm{r}_{\mathrm{c}} \text { in } \mathrm{CW} \text { and } \mathrm{GW}
\end{aligned}
$$

It was predicted in Proposition II that we would find a higher correlation in responses of workers to the concept of selfdetermination between the hypothetical casework and group work situations that for the situations utilizing the concept of confidentiality. The null hypothesis is that there will be no difference in 
the degree of correlation between casework and group work situations in the use of confidentiality and self-determination. The Pearson Product-Moment Correlation Coefficient was used in determining the degree of correlation between the two methods in the use of the two concepts, self-determination and confidentiality. This test was selected as it is the standard measure of correlation, and is preferred above other correlation techniques because of greater reliability, having a smaller standard error than other methods. (Ruch, 1958) The individual respondents' mean scores from the hypothetical situations of the four sections of the questionnaire were used as quantitative data in these tests of correlation. Workers' judgment of the use of self-determination in cas ework and in group work was first correlated, resulting in a correlation coefficient of -.21 , showing a very weak negative correlation in the use of self-determination between the two social work methods. To test whether this correlation coefficient, "r", is significantly different from zero, reference was made to a table of "r" and "R", which showed a value as high as \pm .312 for "r" was needed to be significant at the p.05 level with 38 degrees of freedom and two variables.

Computing the Pearson Product-Moment Correlation Coefficient for correlation of workers' judgments in the use of confidentiality between casework and group work methods resulted in a 
coefficient of +.41 , a fairly strong positive correlation, statistically significant at the p. 05 level which again called for an "r" of \pm .312 with 38 degrees of freedom and two variables.

On the basis of these correlations and tests, it was evident that the exact opposite of the proposition had occurred in the workers' judgments of the hypothetical situations in the questionnaire. Since the correlation of workers' judgments of self-determination was not significantly different from zero, and since the correlation of workers' judgments of confidentiality. was significantly positive, it appears that neither of the two hypotheses is tenable. It is proposed that the data suggest the following hypothesis:

$$
\mathrm{H}_{2}: \mathrm{r}_{\mathrm{sd}}<\mathrm{r}_{\mathrm{C}} \text { in } \mathrm{CW} \text { and } \mathrm{GW}
$$

Proposition III

Several selected variables will be significantly related to the differential judgment by workers of the two concepts of self-determination and confidentiality in casework and group work. These are: professional education in group work method, other types of training in casework or group work method, preference for the casework or group work method, years of social-work experience, and experience in work with groups.

\section{Professional Education in Group-Work Method}

$$
\begin{aligned}
& \mathrm{H}_{1}: \mathrm{S}_{\mathrm{GWEd}}^{2}>\mathrm{S}_{\text {No GW Ed }}^{2} \text { in } \mathrm{SD} \mathrm{GW} \\
& \mathrm{H}_{0}: \mathrm{S}_{\mathrm{GW}}^{2} \mathrm{Ed}=\mathrm{S}^{2} \text { No GWEd in } \mathrm{SD} \mathrm{GW}
\end{aligned}
$$




$$
\begin{aligned}
& H_{1}: s_{G W E d}^{2}>S^{2} \text { No GW Ed in Conf GW } \\
& \mathrm{H}_{0}: \mathrm{S}_{\mathrm{GWE}}^{2}=\mathrm{S}^{2} \text { No GW Ed in Conf GW } \\
& \mathrm{H}_{1}: \mathrm{S}_{\mathrm{GWEd}}^{2}>\mathrm{S}^{2} \text { No GW Ed in SD CW } \\
& \mathrm{H}_{0}: \mathrm{S}_{\mathrm{GWEd}}^{2}=\mathrm{S}_{\text {No GW Ed }}^{2} \text { in } S D \mathrm{CW} \\
& \mathrm{H}_{1}: \mathrm{S}_{\mathrm{GWEd}}^{2}>\mathrm{S}^{2} \text { No GW Ed in Conf CW } \\
& \mathrm{H}_{0}: \mathrm{S}^{2} \mathrm{GWEd}=\mathrm{S}^{2} \text { No GW Ed in Conf CW }
\end{aligned}
$$

It was predicted that there would be more variance in the judgments of the hypothetical situations by those workers who did have group work education and less variance in judgments by workers who lack this education, since the workers with group work education would have a broader perceptual set. The $F$ Test was selected to test the variable of professional education in group work method, because it is described as being among the sharpest and most powerful of statistical tools for testing variance. (Ruch, 1958) The F Test also permits comparison of unequal sized groups. This was important in planning the statistical procedures, as it was anticipated that the percentage of the sample having group work education would be smaller than the percentage having only cas ework education in preparation for a master's degree. It was assumed that the data being tested represented a normal distribution. (Siege1, 1956) In applying the $F$ Test to the data, the mean scores of the 
respondents having had academic education in group work method were separated from the sample and placed in the four categories, casework and group work in self-determination, and casework and group work in confidentiality. For the second group, only those respondents who indicated having neither graduate education in group work nor additional training in the group work method were selected. This resulted in 24 respondents who indicated having no group work training or education, compared to 11 respondents in the first group who did have academic education in group work method. The F Test was carried out four times between the groups, resulting in the data in the table on the following page.

The null hypotheses were accepted as the $F$ Ratios were not significant at the p.05 level, although it was evident in each case that there was greater variance in the scores in both casework and group work of the respondents having had group work education.

$$
\begin{aligned}
& \mathrm{H}_{0}: \mathrm{S}_{\mathrm{GWEd}}^{2}=\mathrm{S}^{2}{ }_{\text {No }} \mathrm{GWEd} \text { in } \mathrm{SD} \mathrm{GW} \text {, accepted. } \\
& \mathrm{H}_{0}: \mathrm{S}_{\mathrm{GWEd}}^{2}=\mathrm{S}^{2} \text { No GW Ed in Conf GW, accepted. } \\
& \mathrm{H}_{0}: \mathrm{S}_{\mathrm{GWEd}}^{2}=\mathrm{S}^{2} \text { No GWEd in SD CW, accepted. } \\
& \mathrm{H}_{0}: \mathrm{S}_{\mathrm{GWE}}^{2}=\mathrm{S}^{2} \text { No GW Ed in Conf CW, accepted. }
\end{aligned}
$$

\section{Other Training in Group Work Method}

It was predicted that workers who did have training in group 
TABLE II

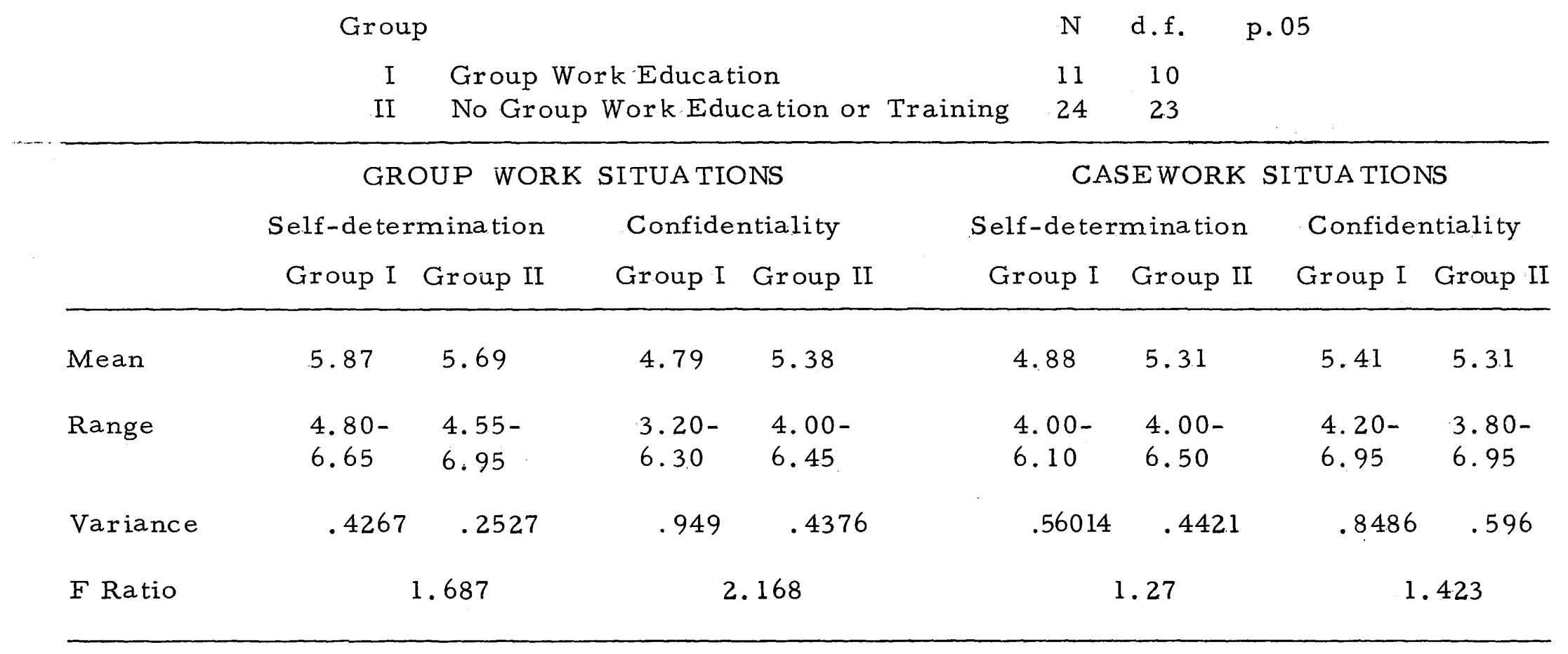


work method, other than academic education, would show a greater variance in their judgments of the use of self-determination and confidentiality in the hypothetical casework and group work situations than those workers who had no training or education in group work method.

$$
\begin{aligned}
& \mathrm{H}_{1}: \mathrm{S}^{2} \mathrm{GW} \operatorname{Tr}>\mathrm{S}^{2} \text { No GW } \operatorname{Tr} \text { in } \mathrm{SD} G W \\
& \mathrm{H}_{0}: \mathrm{S}_{\mathrm{GW}}^{2} \mathrm{Tr}=\mathrm{S}^{2} \text { No GW Tr in SD GW } \\
& \mathrm{H}_{1}: \mathrm{S}^{2} \mathrm{GW} \operatorname{Tr}>\mathrm{S}^{2} \text { No GW Tr in Conf GW } \\
& \mathrm{H}_{0}: \mathrm{S}_{\mathrm{GW}}^{2} \mathrm{Tr}=\mathrm{S}^{2} \text { No GW Tr in Conf GW } \\
& \mathrm{H}_{1}: \mathrm{S}^{2} \mathrm{GW} \operatorname{Tr}>\mathrm{S}^{2} \text { No GW Tr in } \mathrm{SDCW} \\
& \mathrm{H}_{0}: \mathrm{S}^{2} \mathrm{GW} \operatorname{Tr}=\mathrm{S}^{2} \text { No GW Tr in SD CW } \\
& \mathrm{H}_{1}: \mathrm{S}^{2} \mathrm{GW} \operatorname{Tr}>\mathrm{S}^{2} \text { No GW } \operatorname{Tr} \text { in Conf CW } \\
& \mathrm{H}_{0}: \mathrm{S}^{2} \mathrm{GW} \operatorname{Tr}=\mathrm{S}^{2} \text {. No GW Tr in Conf } \mathrm{CW}
\end{aligned}
$$

The $F$ Test was again applied, in this instance comparing the variance of those respondents who indicated having had group work training in seminars, in-service-training workshops, staff development, and institutes, with those who had no group work training. There were five respondents who had training of this type in group work method. This group was paired with the group of 24 respondents who had indicated having no training or education in 
group work whatever. The results of the $F$ Test are shown in Table III.

As none of the $F$ ratios were significant at the p. 05 level, the null hypotheses were accepted in all cases.

$$
\begin{aligned}
& \mathrm{H}_{0}: \mathrm{S}_{\mathrm{GW}}^{2} \operatorname{Tr}=\mathrm{S}^{2} \text {. No GW } \operatorname{Tr} \text { in } \mathrm{SD} G W \text {, accepted. } \\
& \mathrm{H}_{0}: \mathrm{S}_{\mathrm{GW}}^{2} \mathrm{Tr}=\mathrm{S}^{2} \text { No GW } \operatorname{Tr} \text { in Conf GW, accepted. } \\
& \mathrm{H}_{0}: \mathrm{S}^{2} \mathrm{GW} \operatorname{Tr}=\mathrm{S}^{2} \text { No } \mathrm{GW} \operatorname{Tr} \text { in } \mathrm{SD} \mathrm{CW} \text {, accepted. } \\
& \mathrm{H}_{0}: \mathrm{S}_{\mathrm{GW}}^{2} \mathrm{Tr}=\mathrm{S}^{2} \text { No } \mathrm{GW} \operatorname{Tr} \text { in Conf } \mathrm{CW} \text {, accepted. }
\end{aligned}
$$

Although not statistically significant, the evidence does show that those workers who had additional group work training such as seminars and institutes, showed a greater variance in scores in all instances except for the use of self-determination in casework situations .

\section{Other Training in Casework Method}

It was also predicted that the workers who had additional training in casework method would reflect a broader perceptual set by more variance in judgments in the use of the two concepts, self-determination and confidentiality, in the hypothetical situations.

$$
\begin{aligned}
& \mathrm{H}_{1}: \mathrm{S}^{2} \mathrm{CW} \operatorname{Tr}>\mathrm{S}^{2} \text { No } \mathrm{CW} \operatorname{Tr} \text { in SDCW } \\
& \mathrm{H}_{0}: \mathrm{S}^{2} \mathrm{CW} \operatorname{Tr}=\mathrm{S}_{\text {No } C W}^{2} \operatorname{Tr} \text { in } \mathrm{SDCW}
\end{aligned}
$$


TABLE III

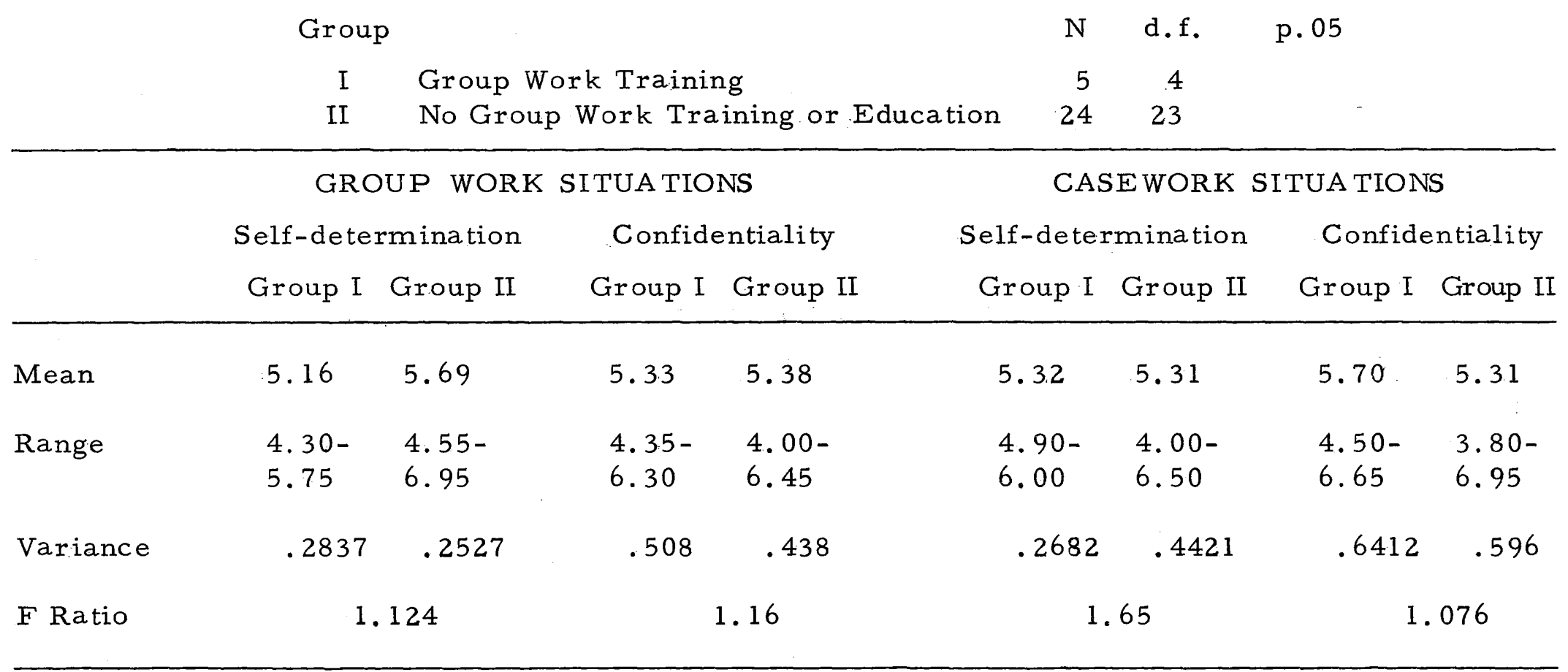




$$
\begin{aligned}
& \mathrm{H}_{1}: \mathrm{S}^{2} \mathrm{CW} \operatorname{Tr}>\mathrm{S}^{2} \text { No } \mathrm{CW} \operatorname{Tr} \text { in Conf CW } \\
& \mathrm{H}_{0}: \mathrm{S}^{2} \mathrm{CW} \operatorname{Tr}=\mathrm{S}^{2} \text { No } \mathrm{CW} \operatorname{Tr} \text { in Conf CW } \\
& \mathrm{H}_{1}: \mathrm{S}_{\mathrm{CW}}^{2} \mathrm{Tr}>\mathrm{S}^{2} \text { No CW Tr in } \mathrm{SD} G W \\
& \mathrm{H}_{0}: \mathrm{S}^{2} \mathrm{CW} \operatorname{Tr}=\mathrm{S}^{2} \text { No } \mathrm{CW} \operatorname{Tr} \text { in } \mathrm{SD} G W \\
& \mathrm{H}_{1}: \mathrm{S}^{2} \mathrm{CW} \operatorname{Tr}>\mathrm{S}^{2} \text { No } \mathrm{CW} \operatorname{Tr} \text { in Conf } \mathrm{GW} \\
& \mathrm{H}_{0}: \mathrm{S}^{2} \mathrm{CW} \mathrm{Tr}=\mathrm{S}^{2} \text { No } \mathrm{CW} \operatorname{Tr} \text { in Conf GW }
\end{aligned}
$$

Nine respondents in the sample indicated that they did have further training in casework method following completion of academic work for a master's degree. The F Test was again applied to this data, with comparison of variances between the nine respondents having additional training in casework method and the 31 respondents having no additional casework training. The $F$ Ratios of these two groups in the use of the two concepts in the hypothetical situations are shown in Table IV.

As the $F$ Ratios between workers who had additional training in casework method and those workers who had no additional training in casework method were not statistically significant at the p. 05 level, the null hypotheses were accepted. There was not significantly greater variance in scores of the workers' judgments for those workers who did have other training in casework method. However, those workers with additional casework training showed 
TABLE IV

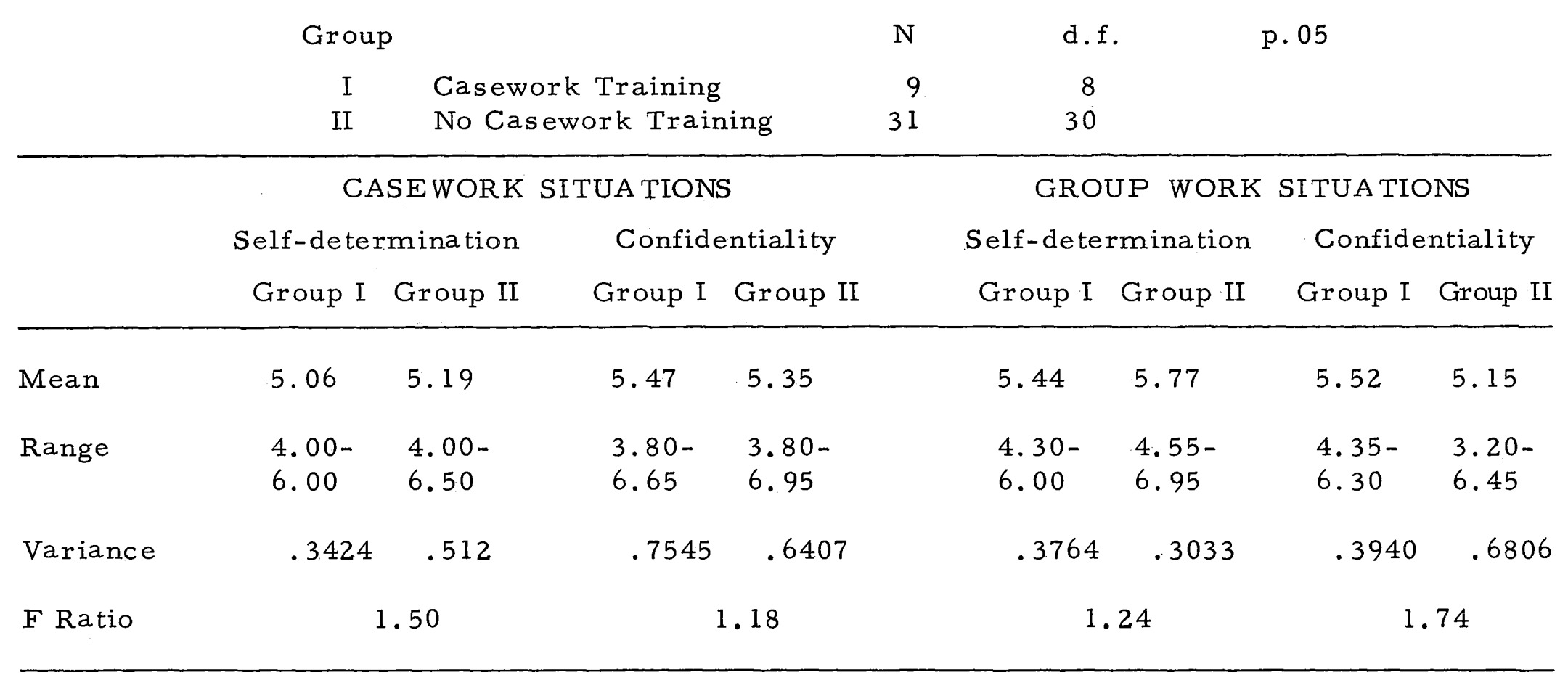


greater variance in the use of confidentiality in casework situations, and in the use of self-determination in group work situations.

$$
\begin{aligned}
& \mathrm{H}_{0}: \mathrm{S}^{2} \mathrm{CW} \mathrm{Tr}=\mathrm{S}^{2} \text { No } \mathrm{CW} \operatorname{Tr} \text { in } \mathrm{SD} C W \text {, accepted. } \\
& \mathrm{H}_{0}: \mathrm{S}_{\mathrm{CW}}^{2} \mathrm{Tr}=\mathrm{S}_{\text {No } \mathrm{CW}}^{2} \operatorname{Tr} \text { in Conf } \mathrm{CW} \text {, accepted. } \\
& \mathrm{H}_{0}: \mathrm{S}^{2} \mathrm{CW} \operatorname{Tr}=\mathrm{S}^{2} \text { No } \mathrm{CW} \operatorname{Tr} \text { in } \mathrm{SD} G W \text {, accepted. } \\
& \mathrm{H}_{0}: \mathrm{S}^{2} \mathrm{CW} \operatorname{Tr}=\mathrm{S}^{2} \text { No CW Tr in Conf GW, accepted. }
\end{aligned}
$$

Other Training in both Casework and Group Work Method

No statistical procedures were carried out for this variable, since only four respondents indicated that they had additional training in both casework and group work method.

\section{Preference for Casework or Group Work Method}

No statistical test was applied to the data for this variable because only three respondents indicated a preference for group work. In addition, two respondents stated they preferred neither method. However, it was interesting to note that the three respondents preferring group work method had an exceedingly low group mean score, 4.28 , in the use of confidentiality in group work in the hypothetical situations. Their other mean scores were comparable to the other groups having either group work education or group 
work training. These three persons did have graduate education in group work.

Years of Social Work Experience

It was predicted that there would be a correlation between years of social work experience and scores of workers' judgments of the hypothetical situations in the use of self-determination and confidentiality in the two social-work methods.

$\mathrm{H}_{1}: \gamma_{\mathrm{S}} \mathrm{SW}$ Exp vs SD CW $\neq 0 \quad \mathrm{H}_{1}: \gamma_{\mathrm{S}} \mathrm{SW}$ Exp vs Conf CW $\neq 0$

$\mathrm{H}_{0}: \gamma_{\mathrm{S}} \mathrm{SW}$ Exp vs SD CW $=0 \quad \mathrm{H}_{0}: \gamma_{\mathrm{s}}$ SW Exp vs Conf CW $=0$

$\mathrm{H}_{1}: \gamma_{\mathrm{S}} \mathrm{SW} \operatorname{Exp}$ vs SD GW $\neq 0 \quad \mathrm{H}_{1}: \gamma_{\mathrm{s}} \mathrm{SW} \operatorname{Exp}$ vs Conf GW $\neq 0$

$H_{0}: \gamma_{S}$ SW Exp vs SD GW $=0 \quad H_{0}: \gamma_{s}$ SW Exp vs Conf GW $=0$

The Spearman Rank Correlation was applied to the data of years of social work experience in relation to mean scores of individual respondents in each of the four categories, casework and group work in self-determination, and casework and group work in confidentiality, to determine existance of relationships. It was assumed that the data met two requirements necessary for this procedure, homoscedasticity and linearity of regression. (Ruch, 1958) To determine if these correlation values were significant at the p. 05 level, they were converted into "t" scores, as the number 
of scores was over 30 . The correlation values and corresponding "t" values were:

$\begin{array}{llc} & \frac{\gamma_{s}}{{ }} & -1 t^{\prime \prime} \\ \text { Self-determination in casework } & +.364 & +2.41 \\ \text { Self-determination in group work } & -.12 & -.355 \\ \text { Confidentiality in casework } & +.026 & +.051 \\ \text { Confidentiality in group work } & -.0119 & -.037\end{array}$

The correlation value, $\gamma_{s}$, of +.364 for self-determination in casework was significant at the p. 05 level, with $N=40$, d.f. 38 ; therefore, the alternate hypothesis was accepted in that there was a significant positive correlation between scores of workers' judgments and years of social work experience in the use of selfdetermination in the hypothetical casework situations. Since no significant correlation value existed between years of social. work experience and scores of workers' judgments in self-determination in group work, and in confidentiality in both casework and group work in the hypothetical situations, these three null hypotheses were accepted at the p. 05 level.

$$
\begin{aligned}
& \mathrm{H}_{1}: \gamma_{\mathrm{s}} \mathrm{SW} \operatorname{Exp} \text { vs SD CW } \neq 0 \text {, accepted. } \\
& \mathrm{H}_{0}: \gamma_{\mathrm{S}} \mathrm{SW} \text { Exp vs SD GW }=0 \text {, accepted. } \\
& \mathrm{H}_{0}: \gamma_{\mathrm{s}} \mathrm{SW} \operatorname{Exp} \text { vs Conf CW }=0 \text {, accepted. } \\
& \mathrm{H}_{0}: \gamma_{\mathrm{s}} \mathrm{SW} \text { Exp vs Conf } \mathrm{GW}=0 \text {, accepted. }
\end{aligned}
$$


Although not statistically significant, there was a slightly negative correlation between years of social work experience and the use of self-determination in group work; a slightly positive correlation between years of social work experience and the use of confidentiality in casework; a very slight negative correlation between years of social work experience and the use of confidentiality in group work.

\section{Experience with Groups}

It was predicted that those workers who had experience with groups would also show a wider variance, reflecting a broader perceptual set, in the scores of their judgments of the hypothetical situations, than those workers who did not have experience in working with groups.

$$
\begin{aligned}
& \mathrm{H}_{1}: \mathrm{S}^{2} \operatorname{Exp} \mathrm{Gr}>\mathrm{S}^{2} \text { No } \operatorname{Exp} \mathrm{Gr} \text { in } \mathrm{SDCW} \\
& \mathrm{H}_{0}: \mathrm{S}^{2} \operatorname{Exp} \mathrm{Gr}=\mathrm{S}^{2} \text { No } \operatorname{Exp} \mathrm{Gr} \text { in } \mathrm{SD} \mathrm{CW} \\
& \mathrm{H}_{1}: \mathrm{S}^{2} \operatorname{Exp} \mathrm{Gr}>\mathrm{S}^{2} \text { No Exp Gr in.Conf CW } \\
& \mathrm{H}_{0}: \mathrm{S}^{2} \operatorname{Exp} \mathrm{Gr}=\mathrm{S}^{2} \text { No Exp Gr in Conf CW } \\
& \mathrm{H}_{1}: \mathrm{S}^{2} \operatorname{Exp} \mathrm{Gr}>\mathrm{S}^{2} \text { No } \operatorname{Exp} \mathrm{Gr} \text { in } \mathrm{SD} G W \\
& H_{0}: S^{2} \operatorname{Exp} G r=S^{2} \text { No } \operatorname{Exp} G r \text { in } S D G W \\
& \mathrm{H}_{1}: \mathrm{S}_{\operatorname{Exp} \mathrm{Gr}}^{2}>\mathrm{S}^{2} \text { No Exp Gr in Conf GW }
\end{aligned}
$$




$$
\mathrm{H}_{0}: \mathrm{S}^{2} \operatorname{Exp} \mathrm{Gr}=\mathrm{S}^{2} \text { No Exp Gr in Conf GW }
$$

For this variable, the $F$ Test was again selected to determine the influence of the workers' experience upon their individual mean scores of their judgments of the hypothetical situations. Nineteen respondents indicated having had experience in group work, compared to twenty-one respondents who had no experience with groups. The following table shows the results of those $F$ Tests in the use of the two concepts in the hypothetical situations.

The F Ratio of 2.72 of workers' judgements in the use of confidentiality in the hypothetical casework situations was significant at the p. 05 level, reflecting the greater variance of the respondents who had group work experience. These respondents also showed a greater variance in the judgments of the use of confidentiality in group work and the use of self-determination in casework, although the $F$ ratios were not statistically significant at the p. 05 level. We were able, therefore, to accept the alterna te hypothesis for workers' judgments of the use of confidentiality in cas ework, that those workers having had experience in working with groups would have a greater variance of scores than those workers who had no group work experience. The null hypotheses were accepted for the three other categories, use of self-determination in group 
TABLE V

$\begin{array}{clccc}\text { Group } & & \text { N } & \text { d.f. } & \text { p.05 } \\ \text { I } & \text { Group Work Experience } & 19 & 18 & \\ \text { II } & \text { No Group Work Experience } & 21 & 20 & \end{array}$

\begin{tabular}{|c|c|c|c|c|c|c|c|c|}
\hline & \multicolumn{4}{|c|}{ GROUP WORK SITUA TIONS } & \multicolumn{4}{|c|}{ CASEWORK SITUA TIONS } \\
\hline & \multicolumn{2}{|c|}{ Self-determination } & \multicolumn{2}{|c|}{ Confidentiality } & \multicolumn{2}{|c|}{ Self-determination } & \multicolumn{2}{|c|}{ Confidentiality } \\
\hline & Group I & Group II & Group I & Group II & Group I & Group II & Group I & Group II \\
\hline Mean & 5.84 & 5.57 & 5.12 & 5.28 & 5.59 & 5.06 & 5.36 & 5.41 \\
\hline Range & $\begin{array}{l}5.15- \\
6.95\end{array}$ & $\begin{array}{l}4.30- \\
6.30\end{array}$ & $\begin{array}{l}3.20- \\
6.30\end{array}$ & $\begin{array}{l}4.20- \\
6.45\end{array}$ & $\begin{array}{l}4.00- \\
6.50\end{array}$ & $\begin{array}{l}4.00- \\
6.50\end{array}$ & $\begin{array}{l}3.80- \\
6.95\end{array}$ & $\begin{array}{l}4.50- \\
6.95\end{array}$ \\
\hline Variance & .3216 & .3309 & .7351 & .5377 & .6951 & .3679 & 1.0001 & .3676 \\
\hline F Ratio & & 028 & & 39 & & 89 & & .72 \\
\hline
\end{tabular}


work, use of confidentiality in group work, and use of selfdetermination in casework.

$$
\begin{aligned}
& \mathrm{H}_{1}: \mathrm{S}^{2} \operatorname{Exp} \mathrm{Gr}>\mathrm{S}^{2} \text { No } \operatorname{Exp} \mathrm{Gr} \text { in Conf } \mathrm{CW} \text {, accepted. } \\
& \mathrm{H}_{0}: \mathrm{S}_{\operatorname{Exp} \mathrm{Gr}}^{2}=\mathrm{S}^{2} \text { No Exp Gr} \text { in } \mathrm{SDCW} \text {, accepted. } \\
& \mathrm{H}_{0}: \mathrm{S}^{2} \operatorname{Exp} \mathrm{Gr}=\mathrm{S}^{2} \text { No } \operatorname{Exp} \mathrm{Gr} \text { in Conf GW, accepted. } \\
& \mathrm{H}_{0}: \mathrm{S}_{\operatorname{Exp} \mathrm{Gr}}^{2}=\mathrm{S}^{2} \text { No } \operatorname{Exp} \mathrm{Gr} \text { in } \mathrm{SD} \mathrm{GW} \text {, accepted. }
\end{aligned}
$$

\section{Analysis of Content}

The following analysis of content reviews each practice principle, the casework and group work situation used to exemplify it, and the frequency that each of the four choices (that had been weighted from least to most indicative of the concept) were chosen by the respondents. Finally, the reasons for choice and their frequency are itemized for all of the practice situations in the schedule. 
The social worker recognizes his limitations in forcing change upon another person whose internal needs and conflicts are complex; therefore he sees his role chiefly as one of stimulating thought about altemative choices without removing responsibility from the client.

CASEWORK SITUATION: You are a worker in a family service agency where your assignment is to provide short-term counselling to an 18 year old girl considering marriage to a college student.

TABLE VI

POSSIBLE CHOICES, WEIGHTING, AND FREOUENCY OF CHOICE OF CASEWORK SITUATION OF PRACTICE PRINCIPLE I OF SELF - DETERMINATION

\begin{tabular}{|c|c|c|}
\hline Possible Choices & $\begin{array}{l}\text { Weighting } \\
\text { (least to } \\
\text { most) }\end{array}$ & $\begin{array}{l}\text { Frequency } \\
\text { of } \\
\text { Choice }\end{array}$ \\
\hline $\begin{array}{l}\text { Advise the girl not to marry because she would have to work to } \\
\text { support the family as long as the boy remains in school. In addi- } \\
\text { tion, she will be able to choose a husband more wisely when she } \\
\text { is a little older. }\end{array}$ & 1.00 & 0 \\
\hline $\begin{array}{l}\text { Suggest the girl "go steady" for at least a year and then reconsider } \\
\text { whether she wishes to marry. }\end{array}$ & 3.25 & 0 \\
\hline $\begin{array}{l}\text { Tell the girl some of the difficulties you forsee in an early marri- } \\
\text { age but it is up to her to make her own decision. She can make } \\
\text { marriage a.success if she is willing to work at it. }\end{array}$ & 4.75 & 3 \\
\hline $\begin{array}{l}\text { Discuss with the girl both the advantages and disadvantages of } \\
\text { early marriage in general and some of the pros and cons of her } \\
\text { particular situation but refrain from making a recommendation. }\end{array}$ & 7.00 & 37 \\
\hline
\end{tabular}

Reasons for Choice:

$$
\text { Frequency of Choice } \quad \mathrm{N}=40
$$

Practice Principle I 21

Practice Principle V 5

Concept 5

Practice Principle II 4

Further Diagnosis 2

Practice Principle III 1

Situation 1

No Answer 
The social worker recognizes his limitations in forcing change upon another person whose internal needs and conflicts are complex; therefore, he sees his role chiefly as one of stimulating thought about alternative choices without removing responsibility from the client.

GROUP WORK SITUATION: You are a worker in a home for unwed mothers. In a group meeting you encounter the problem of a new girl being subjected to group criticism because she does not do her share of the work.

TABLE VII

POSSIBLE CHOICES, WEIGHTING, AND FREQUENCY OF CHOICE OF GROUP WORK SITUATION OF PRACTICE PRINCIPLE II OF SELF-DETERMINATION

\begin{tabular}{lcc}
\hline \multicolumn{1}{c}{ Possible Choices $\quad \mathrm{N}=40$} & $\begin{array}{c}\text { Weighting } \\
\text { (least to } \\
\text { most) }\end{array}$ & $\begin{array}{c}\text { Frequency } \\
\text { of } \\
\text { Choice }\end{array}$ \\
\hline $\begin{array}{l}\text { Intercede and tell the group to quit hazing the newcomer. } \\
\begin{array}{l}\text { Remind the group how it was for them when they first came and } \\
\text { suggest they give the new girl time to learn how to do things. }\end{array}\end{array}$ & 3.00 \\
$\begin{array}{l}\text { Praise the group for its help to new girls and invite their sug- } \\
\text { gestions as to how the orientation process might be made more } \\
\text { pleasant for all concerned. }\end{array}$ & 5.50 \\
$\begin{array}{l}\text { Refrain from comment, believing that the other girls will } \\
\text { soon accept the newcomer as she becomes more conforming. }\end{array}$ & 7.00 \\
\hline
\end{tabular}

Reasons for Choice:

$$
\text { Frequency of Choice } \quad \mathrm{N}=40
$$

Practice Principle I Practice Principle V Practice Principle III Practice Principle IV

Further Diagnosis

Concept

Group Values

No Answer

Situation

Practice Principle II 
The social worker refrains from imposing upon clients his own values, goals, and methods of performance in order to protect the right of the clients to make their own decisions.

CASEWORK SITUATION: You are a worker who takes a teenage girl from a foster home on a shopping trip for clothing. The girl likes and wishes to buy a dress that you consider too short and close-fitting for best appearance.

TABLE VIII

POSSIBLE CHOICES, WEIGHTING, AND FREOUENCY OF CHOICE OF CASEWORK SITUATION OF PRACTICE PRINCIPLE II OF SELF-DETERMINATION

\begin{tabular}{|c|c|c|}
\hline Possible Choices & $\begin{array}{l}\text { Weighting } \\
\text { (least to } \\
\text { most) }\end{array}$ & $\begin{array}{c}\text { Frequency } \\
\text { of } \\
\text { Choice }\end{array}$ \\
\hline Tell the teenager she cannot buy the dress. & 1.00 & 6 \\
\hline Ask the salesgirl to find the same dress in a larger size. & 2.75 & 19 \\
\hline $\begin{array}{l}\text { Allow the teenager to buy the dress with the stipulation that she } \\
\text { must let the hem down. }\end{array}$ & 4.50 & 3 \\
\hline $\begin{array}{l}\text { Allow the teenager to buy the dress as it is without making any } \\
\text { stipulation for change. }\end{array}$ & 7.00 & 12 \\
\hline
\end{tabular}

Reasons for Choice:

$$
\text { Frequency of Choice } \quad \mathrm{N}=40
$$

Practice Principle II 10

Practice Principle IV 10

Practice Principle I 7

Bearer of Community Values 4

No Self-Determination 3

Practice Principle V 3

Situation

No Answer

Practice Principle III 
The social worker refrains from imposing upon clients his own values, goals, and methods of performance in order to protect the right of the clients to make their own decisions.

GROUP WORK SITUATION: You are a worker assigned to a girls' club which meets at a settlement house. Members are thirteen and fourteen years old. They are planning a party and want to invite boys and wear their "grubbies". (informal clothing)

TABLE IX

POSSIBLE CHOICES, WEIGHTING, AND FREQUENCY OF CHOICE OF GROUP WORK SITUATION OF PRACTICE PRINCIPLE II OF SELF-DETERMINATION

\begin{tabular}{lcc}
\multicolumn{1}{c}{ Possible Choices $\quad \mathrm{N}=40$} & $\begin{array}{c}\text { Weighting } \\
\text { (least to } \\
\text { most) }\end{array}$ & $\begin{array}{c}\text { Frequency } \\
\text { of } \\
\text { Choice }\end{array}$ \\
\hline $\begin{array}{l}\text { Suggest they should not ask boys because they are too young to } \\
\text { be dating. }\end{array}$ & 1.50 & 1 \\
$\begin{array}{l}\text { Suggest they wear dressier clothing since boys behave in a more } \\
\text { gentlemanly fashion when dressed up. }\end{array}$ & 3.75 & 11 \\
$\begin{array}{l}\text { Remind them of the last party when some of the boys tore down } \\
\text { decorations and were in other ways not well-mannered. }\end{array}$ & 4.25 \\
$\begin{array}{l}\text { Refrain from making any suggestions to the group as to guests } \\
\text { or dress. }\end{array}$ & 7.00 & 23 \\
\hline
\end{tabular}

Reasons for Choice:

$$
\text { Frequency of Choice } \quad \mathrm{N}=40
$$

Practice Principle II 18

Practice Principle I 9

Practice Principle IV 4

Bearer of Community Values 3

Practice Principle V 3

Situation 2

No Answer 1 
The social worker guides clients toward finding new ways to solve their problems so that clients may retain their self-respect and increase their confidence.

CASEWORK SITUATION: You are a worker in a public welfare agency assigned to a family consisting of a mother and young children. The mother prefers to live in a house with neither water nor electricity, which does not provide protection from the weather. Although entitled to an increased amount of money to cover the cost of better housing, the mother claims their way of life to be emotionally healthy.

TABLE X

POSSIBLE CHOICES, WEIGHTING, AND FREQUENCY OF CHOICE OF CASEWORK SITUATION OF PRACTICE PRINCIPLE III OF SELF-DETERMINATION

\begin{tabular}{|c|c|c|}
\hline Possible Choices & $\begin{array}{l}\text { Weighting } \\
\text { (least to } \\
\text { most) }\end{array}$ & $\begin{array}{l}\text { Frequency } \\
\text { of } \\
\text { Choice }\end{array}$ \\
\hline $\begin{array}{l}\text { Infer that unless a change is made, there may be legal action } \\
\text { concerning the children remaining in the home. }\end{array}$ & 1.00 & 0 \\
\hline Locate other housing for the family. & 2.75 & 2 \\
\hline $\begin{array}{l}\text { Suggest the mother look for other housing that more nearly } \\
\text { meets the community standard for decency and health. }\end{array}$ & 5.00 & 10 \\
\hline $\begin{array}{l}\text { Continue to provide financial aid to the family and refrain } \\
\text { from discussing the housing situation further. }\end{array}$ & 6.75 & 28 \\
\hline
\end{tabular}

Reasons for Choice:

$$
\text { Frequency of Choice } \quad \mathrm{N}=40
$$

Practice Principle III 14

Bearer of Community Values 11

(for protection of children)

Practice Principle I

Further Diagnosis

3

Situation

No Answers

Concept

14
11
6
3
3
1
1
1


The social worker guides clients toward finding new ways to solve their problems so that clients may retain their self-respect and increase their confidence.

GROUP WORK SITUATION: You are a worker who meets weekly with a group of ADC mothers to discuss some of their problems. In the course of a meeting, the mothers express concern regarding supervision of their adolescent children.

TABLE XI

POSSIBLE CHOICES, WEIGHTING, AND FREQUENCY OF CHOICE OF GROUP WORK SITUATION OF PRACTICE PRINCIPLE III OF SELF-DETERMINATION

\begin{tabular}{|c|c|c|}
\hline Possible Choices & $\begin{array}{l}\text { Weighting } \\
\text { (least to } \\
\text { most) }\end{array}$ & $\begin{array}{l}\text { Frequency } \\
\text { of } \\
\text { Choice }\end{array}$ \\
\hline $\begin{array}{l}\text { Tell them they should insist their children report where they } \\
\text { are going, whom they will be with, and set a definite time for } \\
\text { them to be home. }\end{array}$ & 1.00 & 6 \\
\hline $\begin{array}{l}\text { Advise them to read a book on Living With Your Teenager which } \\
\text { will help them understand how children feel and act. }\end{array}$ & 3.50 & 9 \\
\hline $\begin{array}{l}\text { Suggest they discuss further some specific problems such as } \\
\text { dating, staying out late, drinking. }\end{array}$ & 4.25 & 5 \\
\hline $\begin{array}{l}\text { Suggest that some of them have experience with teenagers } \\
\text { which they might like to share so as to be helpful to others } \\
\text { who have questions. }\end{array}$ & 6.75 & 20 \\
\hline
\end{tabular}

Reasons for Choice:

Frequency of Choice $\quad \mathrm{N}=40$

Practice Principle III

Practice Principle V

Practice Principle I

No Self-Determination

Concept

Practice Principle II

No Answer

Compliments Group Methods

20
9
5
2
1
1
1
1


The social worker should be aware of a client's capacity to act for himself in order that the worker does not expect self-determination beyond that which is possible for the client.

CASEWORK SITUATION: You are a worker in a public welfare agency. An aged client who lives alone in a rural area is reported by neighbors to have fainting spells. They believe he should be taken to an old people's home. However, the client is sentimentally attached to his home where he has lived for many years.

TABLE XII

POSSIBLE CHOICES, WEIGHTING, AND FREQUENCY OF CHOICE OF CASEWORK SITUATION OF PRACTICE PRINCIPLE IV OF SELF-DETERMINATION

\begin{tabular}{|c|c|c|}
\hline Possible Choices & $\begin{array}{l}\text { Weighting } \\
\text { (least to } \\
\text { most) }\end{array}$ & $\begin{array}{c}\text { Frequency } \\
\text { of } \\
\text { Choice }\end{array}$ \\
\hline $\begin{array}{l}\text { Tell him the names of several hames for the elderly and insist he } \\
\text { make a decision as to which home he will go. }\end{array}$ & 1.25 & 10 \\
\hline $\begin{array}{l}\text { Make arrangements for him to visit several homes for elderly } \\
\text { persons. }\end{array}$ & 2.25 & 3 \\
\hline $\begin{array}{l}\text { Point out various possibilities open to him in sheltered living } \\
\text { situations. }\end{array}$ & 5.00 & 23 \\
\hline $\begin{array}{l}\text { Respect the client's decision to stay in his own home and suggest } \\
\text { housekeeping services. }\end{array}$ & 7.00 & 4 \\
\hline
\end{tabular}

Reasons for Choice:

$$
\text { Frequency of Choice } \quad \mathrm{N}=40
$$

Practice Principle IV

Practice Principle I

Practice Principle II

Further Diagnosis

Concept

Situation

No Answer

15
12
6
3
2
1
1


The social worker should be aware of a client's capacity to act for hims elf in order that the worker does not expect self-determination beyond that which is possible for the client.

GROUP WORK SITUATION: You are a worker in a correctional institution who meets with a group of girls aged 16 and 17. They are discussing their forthcoming return to public high schools, are poorly motivated academically, and would like to be excused from further attendance. Oregon compulsory school attendance law states that all children must attend school until they are 18 or graduate from high school unless they are formally excused from school through action of their local school board initiated by their legal guardian.

TABLE XIII

POSSIBLE CHOICES, WEIGHTING, AND FREQUENCY OF CHOICE OF GROUP WORK SITUATION OF PRACTICE PRINCIPLE IV OF SELF-DETERMINATION

\begin{tabular}{lcc}
\hline \multicolumn{1}{c}{ Possible Choices $N=40$} & $\begin{array}{c}\text { Weighting } \\
\text { (least to } \\
\text { most) }\end{array}$ & $\begin{array}{c}\text { Frequency } \\
\text { of } \\
\text { Choice }\end{array}$ \\
\hline $\begin{array}{l}\text { Advise them they must comply with the law. } \\
\text { Say that all of them must at least try public school. If they } \\
\text { fail, their request may be reconsidered. }\end{array}$ & 1.00 & 0 \\
$\begin{array}{l}\text { Tell them it is highly desirable they remain in school for they } \\
\text { cannot get good jobs without more education. }\end{array}$ & 4.00 \\
$\begin{array}{l}\text { Agree to talk with school officials about the possibility that } \\
\text { some of them, depending on their scholastic ability, may be } \\
\text { excused from further school attendance. }\end{array}$ & 4.00 & 7 \\
\hline
\end{tabular}

Reasons for Choice:

Practice Principle IV Community Standards Practice Principle I Further Diagnosis Situation

Practice Principle V Practice Principle III No Answer No Self-Determination

$$
\text { Frequency of Choice } \quad \mathrm{N}=40
$$

17
6
5
4
3
2
1
1
1


The social worker encourages the fullest possible participation of the clients in the working through of their problems so that the clients may increase their ability to find more effective solutions to their needs.

CASEWORK SITUATION: You are a child welfare worker who is approached by a fourteen year old boy who requests that you place him in a different foster home as he complains his present foster parents are too strict and do not understand him. The foster parents admit that the boy is rebelling against family "rules", but are willing to have him remain in their home.

TABLE XIV

POSSIBLE CHOICES, WEIGHTING, AND FREQUENCY OF CHOICE OF CASEWORK SITUATION OF PRACTICE PRINCIPLE V OF SELF-DETERMINATION

\begin{tabular}{|c|c|c|}
\hline Possible Choices & $\begin{array}{c}\text { Weighting } \\
\text { (least to } \\
\text { most) }\end{array}$ & $\begin{array}{c}\text { Frequency } \\
\text { of } \\
\text { Choice }\end{array}$ \\
\hline $\begin{array}{l}\text { Have a talk with the boy, advising him to straighten up and start } \\
\text { following the rules. }\end{array}$ & 1.25 & 2 \\
\hline $\begin{array}{l}\text { Attempt to dissuade the boy from the plan of going to another } \\
\text { foster home, and advise him to make a concerted effort to get } \\
\text { a long for a month's time. If this does not work out, plan to dis- } \\
\text { cuss the problem with him again. }\end{array}$ & 3.25 & 2 \\
\hline $\begin{array}{l}\text { Arrange for the boy to meet with you to consider why he is not } \\
\text { getting along before attempting to find another foster home for } \\
\text { him. }\end{array}$ & 4.75 & 36 \\
\hline $\begin{array}{l}\text { Arrange some trial visits to foster homes for the boy to decide } \\
\text { which home he wants. }\end{array}$ & 7.00 & 0 \\
\hline
\end{tabular}

Reasons for Choice:

Frequency of Choice $\quad \mathrm{N}=40$

Practice Principle V Further Diagnosis Practice Principle IV Practice Principle III Situation

Practice Principle I No Answer 
The social worker encourages the fullest possible participation of the clients in the working through of their problems so that the clients may increase their ability to find more effective solutions to their needs.

GROUP WORK SITUATION: You are a social worker with a group of early adolescent boys who hold activity club meetings in a heighborhood house. The Board of Directors has complained that damage to the building has resulted from overly-rough play of the boys.

TABLE XV

POSSIBLE CHOICES, WEIGHTING, AND FREQUENCY OF CHOICE OF GROUP WOORK SITUATION OF PRACTICE PRINCIPLE $V$ OF SELF-DETERMINATION

\begin{tabular}{|c|c|c|}
\hline Possible Choices & $\begin{array}{l}\text { Weighting } \\
\text { (least to } \\
\text { most) }\end{array}$ & $\begin{array}{c}\text { Frequency } \\
\text { of } \\
\text { Choice }\end{array}$ \\
\hline $\begin{array}{l}\text { Limit their activities to certain sports and insist that there be no } \\
\text { horseplay on the side. }\end{array}$ & 1.75 & 0 \\
\hline $\begin{array}{l}\text { Tell them that any more property damage caused by them will } \\
\text { result in their no longer being able to use the building. }\end{array}$ & 2.25 & 0 \\
\hline Request that the boys be more respectful of the property. & 4.75 & 0 \\
\hline $\begin{array}{l}\text { Discuss the problem with the group, inviting their ideas about } \\
\text { how they could prevent further damage. }\end{array}$ & 7.00 & 40 \\
\hline
\end{tabular}

Reasons for Choice:

Frequency of Choice $\quad \mathrm{N}=40$

Practice Principle V

Practice Principle IV Situation

Practice Principle III

Practice Principle I

Practice Principle II

No Self-Determination

No Answer

28
3
3
2
1
1
1
1


In order to establish basic trust between clients and worker which-is necessary for a social work relationship, the worker will convey to the client by some means of verbal communication, the assurance that personal information revealed by the clients will be used only in the clients' best interests in accordance with the values and ethics of the social work profession.

CASEWORK SITUATION: You are a worker in a family counselling agency where a distraught client comes for help with her marital problems. During one of the early interviews, the client inadvertently reveals the existence of an illegitimate child she has since placed for adoption. Neither her husband nor her friends know about this child and she is admittedly reluctant to discuss the matter further with you.

TABLE XVI

POSSIBLE CHOICES, WEIGHTING, AND FREQUENCY OF CHOICE OF CASEWORK SITUATION OF PRACTIVE PRINCIPLE I OF CONFIDENTIALITY

\begin{tabular}{|c|c|c|}
\hline Possible Choices & $\begin{array}{l}\text { Weighting } \\
\text { (least to } \\
\text { most) }\end{array}$ & $\begin{array}{l}\text { Frequency } \\
\text { of } \\
\text { Choice }\end{array}$ \\
\hline $\begin{array}{l}\text { Inform the client this information will be shared with other legiti- } \\
\text { mate persons who have an honest interest in her welfare. }\end{array}$ & 1.25 & 1 \\
\hline $\begin{array}{l}\text { Inform the client the information will be shared with others within } \\
\text { the agency and with other agencies in order to better help her with } \\
\text { her problems. }\end{array}$ & 2.25 & 0 \\
\hline $\begin{array}{l}\text { Inform the client the information may be shared with others within } \\
\text { the agency in order to facilitate treatment of her problems. }\end{array}$ & 4.00 & 10 \\
\hline $\begin{array}{l}\text { Inform the client personal information will be revealed to no one } \\
\text { without her prior consent. }\end{array}$ & 7.00 & 29 \\
\hline
\end{tabular}

Reasons for Choice:

Frequency of Choice $\quad \mathrm{N}=40$

Practice Principle I 16

Practice Principle III

Concept 10

Situation 1

No Answer 
In order to establish basic trust between client and worker which is necessary for a social work relationship, the worker will convey to the client by some means of verbal communication, the assurance that personal information revealed by the clients will be used only in the client's best interests in accordance with the values and ethics of the social work profession.

GROUP WORK SITUATION: You are a worker who is meeting the first time with a group of mothers whose children are having problems in school. They are hesitant to discuss personal yet pertinent information about their family situations.

TABLE XVII

POSSIBLE CHOICES, WEIGHTING, AND FREQUENCY OF CHOICE OF GROUP WORK SITUATION OF PRACTICE PRINCIPLE I OF CONFIDENTIALITY

\begin{tabular}{|c|c|c|}
\hline Possible Choices & $N=40$ & $\begin{array}{l}\text { Weighting } \\
\text { (least to } \\
\text { most) }\end{array}$ \\
\hline
\end{tabular}

Inform the group they may discuss the content of the group meetings with whomever they want since most parents have similar problems with their children and they would understand.

Inform the group they may discuss what is said in the meetings with spouses and friends who may help with their advice.

1.50

3

Inform the group it is alright if they discuss what is said in the group with their spouses.

Inform the group they can feel free to discuss personal matters during their meetings for what is said in the meetings must remain within the group setting.
1.50

4.50

5

7.00

28

Reasons for Choice:

$$
\text { Frequency of Choice } \quad \mathrm{N} \approx 40
$$

Practice Principle I 23

Group Decision 4

No Confidentiality

(not practical)

No Answer

Concept

Practice Principle III

Situation 
In order to protect the welfare of the community, social workers will purposefully advise their clients to reveal information known to them that would be useful to law enforcement agencies in performing their function of community protection.

CASEWORK SITUATION: You are a worker in a welfare agency. During a regularly scheduled visit with you, a client reveals she recently overheard her brother and a friend planning a bank robbery. The client cannot decide whether to inform the police or to do nothing and run the risk this crime will be committed which will endanger both her brother and the community.

TABLE XVIII

POSSIBLE CHOICES, WEIGHTING, AND FREQUENCY OF CHOICE OF CASEWORK SITUATION OF PRACTICE PRINCIPLE II OF CONFIDENTIALITY

\begin{tabular}{|c|c|c|}
\hline Possible Choices & $\begin{array}{l}\text { Weighting } \\
\text { (least to } \\
\text { most) }\end{array}$ & $\begin{array}{l}\text { Frequency } \\
\text { of } \\
\text { Choice }\end{array}$ \\
\hline $\begin{array}{l}\text { After the client leaves the interview, pick up the telephone and } \\
\text { notify the police of this situation. }\end{array}$ & 1.00 & 0 \\
\hline $\begin{array}{l}\text { Try to convince the client she must notify the police of this situ- } \\
\text { ation but if you are unsuccessful, notify them yourself. }\end{array}$ & 3.00 & 25 \\
\hline $\begin{array}{l}\text { Take no action unless the police should question you concerning } \\
\text { this situation and then be cooperative. }\end{array}$ & 5.25 & 0 \\
\hline $\begin{array}{l}\text { Keep this information private and within the confines of the } \\
\text { worker-client relationship. }\end{array}$ & 7.00 & 15 \\
\hline
\end{tabular}

Reasons for Choice:

$$
\text { Frequency of Choice } \quad \mathrm{N}=40
$$

Practice Principle II 26

Practice Principle I $\quad 7$

Concept 4

No Answer 2

Self-Determination 1 
In order to protect the welfare of the community, social workers will purposefully advise their clients to reveal information known to them that would be useful to law enforcement agencies in performing their function of community protection.

GROUP WORK SITUATION: You are a worker who has established contact with a gang of teenage boys and are holding regular meetings in a local community center. During one of these meetings, a member reveals that the gang has been involved in a series of recent store break-ins in the neighborhood. This information is not known to the local police and if they become aware of it, the boys may incur a severe penalty.

TABLE XIX

POSSIBLE CHOICES, WEIGHTING, AND FREQUENCY OF CHOICE OF GROUP WORK SITUATION OF PRACTICE PRINCIPLE II OF CONFIDENTIALITY

\begin{tabular}{|c|c|c|}
\hline Possible Choices & $\begin{array}{l}\text { Weighting } \\
\text { (least to } \\
\text { most) }\end{array}$ & $\begin{array}{l}\text { Frequency } \\
\text { of } \\
\text { Choice }\end{array}$ \\
\hline Inform the police about this situation as soon as the meeting is over. & 1.25 & 0 \\
\hline $\begin{array}{l}\text { Tell the group they have a week to correct the situation. If they do } \\
\text { not, you may have to turn them over to the police. }\end{array}$ & 3.75 & 2 \\
\hline $\begin{array}{l}\text { Encourage the boys, during the meeting, to reveal their infractions } \\
\text { to the police and volunteer to accompany them to the police } \\
\text { station to assist in any way possible. }\end{array}$ & 5.25 & 2 \\
\hline $\begin{array}{l}\text { Take no action unless the police should question you concerning } \\
\text { this situation, then be cooperative. }\end{array}$ & 6.00 & 36 \\
\hline
\end{tabular}

Reasons for Choice:

Frequency of Choice $\quad \mathrm{N}=40$

Practice Principle II

Practice Principle I

18

Situation

16

No Answer 
In order to maintain a continuity of confidentiality for clients between various workers and agencies, social workers will release private information about their clients only to those who will respect the confidential nature of the information.

CASEWORK SITUATION: You are a worker who finds it necessary to refer your client to another agency where more specialized treatment for his problem is available. However, you are not sure to what degree the confidentiality of the information concerning your client will be respected by the receiving agency.

TABLE XX

POSSIBLE CHOICES, WEIGHTING, AND FREQUENCY OF CHOICE OF CASEWORK SITUATION OF PRACTICE PRINCIPLE III OF CONFIDENTIALITY

\begin{tabular}{llc}
\hline \multicolumn{1}{c}{ Possible Choices $\quad \mathrm{N}=40$} & $\begin{array}{c}\text { Weighting } \\
\text { (least to } \\
\text { most) }\end{array}$ & $\begin{array}{c}\text { Frequency } \\
\text { of } \\
\text { Choice }\end{array}$ \\
\hline $\begin{array}{l}\text { Refer your client to the agency and forward all pertinent informa- } \\
\text { tion to their staff. }\end{array}$ & 1.25 & 10 \\
$\begin{array}{l}\text { Mark all personal information with a confidential stamp and forward } \\
\text { it to the agency. }\end{array}$ & 3.25 & 2 \\
$\begin{array}{l}\text { Contact the agency to determine how the personal information about } \\
\text { your client will be handled before making your decision of referral. } \\
\text { Withhold personal information about your client. }\end{array}$ & 5.50 & 3 \\
\hline
\end{tabular}

Reasons for Choice:

$$
\text { Frequency of Choice } \quad \mathrm{N}=40
$$

Practice Principle III $\quad 34$

Concept 2

No Answer 2

Situation 1

Agency Policy 1 
In order to maintain a continuity of confidentiality for clients between various workers and agencies, social workers will release private information about their clients only to those who will respect the confidential nature of the information.

GROUP WORK SITUATION: You are a worker in a juvenile correctional institution who has been working with a group of adolescents, all of whom have been released within the past thirty days. You are visited by a worker from a social agency who is now working with this group. He requests all the information you have about his clients.

TABLE XXI

POSSIBLE CHOICES, WEIGHTING, AND FREQUENCY OF CHOICE OF GROUP WORK SITUATION OF PRACTICE PRINCIPLE III OF CONFIDENTIALITY

\begin{tabular}{|c|c|c|}
\hline Possible Choices & $\begin{array}{l}\text { Weighting } \\
\text { (least to } \\
\text { most) }\end{array}$ & $\begin{array}{l}\text { Frequency } \\
\text { of } \\
\text { Choice }\end{array}$ \\
\hline Give the worker access to all the information in your files. & 1.00 & 4 \\
\hline $\begin{array}{l}\text { Give the worker access to the files about members of the group } \\
\text { after being assured all information will be kept confidential. }\end{array}$ & 3.25 & 13 \\
\hline $\begin{array}{l}\text { Give the worker access to the information if he has a release } \\
\text { signed by all the group members. }\end{array}$ & 5.25 & 23 \\
\hline $\begin{array}{l}\text { Tell him your files are confidential and you can give him no } \\
\text { information about the group members. }\end{array}$ & 7.00 & 0 \\
\hline
\end{tabular}

Reasons for Choice:

$$
\text { Frequency of Choice } \quad \mathrm{N}=40
$$

Practice Principle III

Concept

Practice Principle I

Situation

No Answer

22
6
4
3
3
2


In order to protect the privacy and integrity of the client, a social worker will not obtain information about a client by requesting it from collateral sources without the client's knowledge and/or consent.

CASEWORK SITUATION: You are a worker in a family service agency who has just completed an interview with a client who is having problems with her marriage. As you review your notes, you discover this client has been known to a particular state mental hospital.

TABLE XXII

POSSIBLE CHOICES, WEIGHTING, AND FREQUENCY OF CHOICE OF CASEWORK SITUATION OF PRACTICE PRINCIPLE IV OF CONFIDENTIALITY

\begin{tabular}{|c|c|c|}
\hline Possible Choices & $\begin{array}{l}\text { Weighting } \\
\text { (least to } \\
\text { most) }\end{array}$ & $\begin{array}{l}\text { Frequency } \\
\text { of } \\
\text { Choice }\end{array}$ \\
\hline $\begin{array}{l}\text { Write the hospital requesting information but do not mention this } \\
\text { to the client. }\end{array}$ & 1.00 & 0 \\
\hline $\begin{array}{l}\text { Send the client a letter telling her you are writing the hospital } \\
\text { for information about her. }\end{array}$ & 3.00 & 0 \\
\hline $\begin{array}{l}\text { Phone the client to ask if you may write the hospital for informa- } \\
\text { tion about her. }\end{array}$ & 4.75 & 5 \\
\hline $\begin{array}{l}\text { Wait a week until the next interview and then ask the client if } \\
\text { you may write the hospital for information about her. }\end{array}$ & 7.00 & 35 \\
\hline
\end{tabular}

Reasons for Choice:

Practice Principle IV

Practice Principle I

Concept

No Answer

Situation

\section{Frequency of Choice $\quad \mathrm{N}=40$}

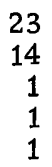


In order to protect the privacy and integrity of the client, a social worker will not obtain information about a client by requesting it from collateral sources without the client's knowledge and/or consent.

GROUP WORK SITUATION: You are a worker in a county welfare department working with a group of ADC mothers. During a group discussion, several of the members mention having participated in group marriage counselling at mental health clinics in other cities. This information was previously unknown to your agency and you would like to have summaries of clinic contacts with these women.

TABLE XXIII

POSSIBLE CHOICES, WEIGHTING, AND FREQUENCY OF CHOICE OF GROUP WORK SITUATION OF PRACTICE PRINCIPLE IV OF CONFIDENTIALITY

\begin{tabular}{|c|c|c|}
\hline Possible Choices & $\begin{array}{l}\text { Weighting } \\
\text { (least to } \\
\text { most) }\end{array}$ & $\begin{array}{l}\text { Frequency } \\
\text { of } \\
\text { Choice }\end{array}$ \\
\hline $\begin{array}{l}\text { Write for the summaries and discuss their implications with the } \\
\text { clients later if pertinent to treatment. }\end{array}$ & 1.75 & 0 \\
\hline $\begin{array}{l}\text { Ask the group to decide if summaries should be obtained about } \\
\text { the members concerned. }\end{array}$ & 2.50 & 7 \\
\hline $\begin{array}{l}\text { Convene a subgroup of those with the prior marriage counseling } \\
\text { experience and ask their permission to write for the summaries. }\end{array}$ & 5.25 & 6 \\
\hline Privately ask each client if you may try to obtain a summary. & 7.00 & 27 \\
\hline
\end{tabular}

Reasons for Choice:

$$
\text { Frequency of Choice } \quad \mathrm{N}=40
$$

Individual decision is needed 22

Practice Principle IV 13

No Answer

Practice Principle I

Concept 
In order to insure the client's right to privacy, the physical facilities will be so arranged that the personal information about clients will be discussed only among those persons who are directly concerned with the treatment.

CASEWORK SITUATION: You are a worker in a settlement house. One of your clients is a neighborhood gang leader who has been referred by the school. After several interviews, he is still quite resistant. You know he has called other boys "sissy" for coming into the settlement house. One afternoon, while a basketball game is in progress, you notice this boy covertly looking in through a window toward your office which opens off the basketball floor. You are aware he has family problems and may need someone to talk to.

TABLE XXIV

POSSIBLE CHOICES, WEIGHTING, AND FREQUENCY OF CHOICE OF CASEWORK SITUATION OF PRACTICE PRINCIPLE V OF CONFIDENTIALITY

$\begin{array}{ll}\text { Possible Choices } \quad \mathrm{N}=40 & \begin{array}{l}\text { Weighting } \\ \text { (least to } \\ \text { most) }\end{array}\end{array}$

Frequency

Call out and invite him in.

1.75

Gently maneuver the boy through the gymnasium and into your office for a private chat.

$2.75 \quad 5$

Take him to a nearby coffee shop and talk to him there.

$\begin{array}{lr}5.00 & 3 \\ 6.75 & 23\end{array}$

the other boys have gone.

Reasons for Choice:

Frequency of Choice $\quad N=40$

Practice Principle V

Establishing a relationship is more important than confidentiality

No Confidentiality

No Answer

Concept

Situation 
In order to insure the client's right to privacy, the physical facilities will be so arranged that the personal information about clients will be discussed only among those persons who are directly concerned with the treatment.

GROUP WORK SITUATION: You are a worker in a family service agency who has just formed a new therapy group. Meetings are to be held each Thursday at 10:00 A. M. in the agency conference room. On the afternoon before the first meeting, you find a meeting of the agency board of directors has been scheduled for the conference room at the same time as your meeting. The board of directors cannot be moved. There is no other room in the agency large enough for your group except the agency lounge which will be unoccupied except for an occasional person crossing it as a shortcut to other areas.

TABLE XXV

POSSIBLE CHOICES, WEIGHTING, AND FREQUENCY OF CHOICE OF GROUP WORK SITUATION OF PRACTICE PRINCIPIE V OF CONFIDENTIALITY

\begin{tabular}{|c|c|c|}
\hline Possible Choices & $\begin{array}{l}\text { Weighting } \\
\text { (least to } \\
\text { most) }\end{array}$ & $\begin{array}{l}\text { Frequency } \\
\text { of } \\
\text { Choice }\end{array}$ \\
\hline $\begin{array}{l}\text { Since the day promises to be warm, hold your meeting on the } \\
\text { patio beside the building. }\end{array}$ & 2.25 & 5 \\
\hline $\begin{array}{l}\text { Schedule your meeting for one corner of the lounge and post } \\
\text { notices of the meeting outside the lounge, realizing this will } \\
\text { not guarantee no one will come through. }\end{array}$ & 2.75 & 12 \\
\hline $\begin{array}{l}\text { Schedule your meeting for one corner of the lounge and use } \\
\text { a portable screen to partially isolate the area. }\end{array}$ & 3.25 & 3 \\
\hline $\begin{array}{l}\text { Reschedule your meeting for the afternoon when the confer- } \\
\text { ence room will be available. }\end{array}$ & 7.00 & 20 \\
\hline
\end{tabular}

Reasons for Choice:

$$
\text { Frequency of Choice } \quad \mathrm{N}=40
$$

Practice Principle V

more important than confidentiality

No Confidentiality

No Answer 


\section{CHAPTER VI}

\section{FINDINGS AND CONCLUSIONS}

The purpose of this exploratory study was to assess, through the judgments of professional social workers, the use of the two concepts, self-determination and confidentiality, in casework and social group work situations. It was assumed by the study group that these two concepts were overlapping referents in casework and group work practice. Community organization and administration methods of social work were omitted from the study as the focus was limited to the two methods of social work practice which provide direct service to clients.

\section{Propositions}

Proposition I stated that the workers' judgments of the use of self-determination and confidentiality would be significantly influenced by the unit of treatment. Proposition I was substantiated only in relation to self-determination. Findings indicated that there was significant difference in the workers' judgments of the use of self-determination in casework and group work practice $\left(X^{2}=11.4\right.$, p. 001 level, d. f. $=1$, for a two-tailed test). In testing the difference in the workers' judgments of the use of confidentiality in casework and group work situations, no significant difference 
was found $\left(x^{2}=.25\right.$, d. f. $=1$, for a two-tailed test, at p. 70 level $)$. The above evidence indicates that the unit of treatment was not significant in workers' judgments of the use of confidentiality, but the unit of treatment was significant in workers' judgments of the use of self-determination in the hypothetical situations.

Proposition II stated that the correlation of workers' judgments of self-determination between the casework and group work situations would be higher than these workers' judgments of confidentiality between the casework and group work situations. Proposition II was not substantiated at the p. 05 level of significance. Evidence showed that there was a non-significant negative correlation between self-determination in casework and group work method. However, in testing the workers' judgments of the use of confidentiality between the casework and group work situations, it was found that the Pearson Product Moment Coefficient equalled +. 41 which was statistically significant at the p. 05 level showing a fairly strong positive correlation between the workers' judgments of the use of confidentiality between the two: methods. On the basis of these correlations and tests, it was evident that the exact opposite of this proposition had occurred in workers' judgments of the hypothetical situations. Since the correlation of workers' judgments of self-determination was not significantly different from zero and since the correlation of workers' judgments of 
confidentiality was significantly positive, it appeared that neither the research nor the null hypothesis were tenable. Therefore, it is proposed that the data suggest the following hypothesis. Correlation in self-determination between casework and group work methods is less than correlation of confidentiality in casework and group work methods.

$$
\mathrm{H}: \mathbf{r}_{\mathrm{sd}}<\mathbf{r}_{\mathrm{C}} \text { in } \mathrm{CW} \text { and } \mathrm{GW} \text {. }
$$

Proposition III stated that several selected variables will be significantly related to the differential judgment by workers of the two concepts of self-determination and confidentiality in casework and group work.

\section{Professional Education in Group Work Method}

It was predicted that there would be more variance in judgments of the hypothetical situations by those workers who did have group work education and less variance in judgments by workers who lacked this education since the workers with group work education would have a broader perceptual set. Although the null hypotheses were accepted as the $\mathrm{F}$ Ratios were not significant at the p. 05 level, it was evident in each case that there was greater variance in the scores in both casework and group work of the respondents having had group work education. 
Other Training in Group Work

It was predicted that workers who did have training in group work method other than academic education would show greater variance in their judgments of the hypothetical situations than those workers who had no training in group work method. As none of the F Ratios were significant at the p.05 level, the null hypotheses were accepted in all cases.

\section{Other Training in Cas ework}

It was also predicted that workers who did have training in casework.method, other than academic education, would show greater variance in their judgments of the hypothetical situations than those workers who had no training. Neither the F Ratios for cas ework nor group work situations showed significant difference for those who had additional training in casework method.

Other Training in Both Cas ework and Group Work

No statistical procedures were carried out for this variable since only four respondents indicated that they had additional training in both methods. 
Preference for Casework or Group Work Method

No statistical procedures were applied to the data for this variable as only three respondents indicated a preference for group work method.

Years of Social Work Experience

It was predicted that there would be a correlation between years of social work experience and the application of workers' judgments in the scores of the hypothetical situations. Significant positive correlation was found between the scores of workers judgments in the use of self-determination in casework and years of social work experience, $\left(\gamma_{s}=+.364\right.$, p. 05 level, d. f. 38). There did not prove to be any significant correlation between years of experience and self-determination in group work judgments, confidentiality and casework judgments, and confidentiality and group work judgments,

Experience in Work With Groups

None of the $F$ Ratios were statistically significant at the p. 05 level except for that $F$ Ratio reflecting workers' judgments in the use of confidentiality in hypothetical casework situations. The variance in the scores of those respondents having group 
work experience was over twice as large as the variance of those respondents having no group work experience in workers' judgments of the use of confidentiality in hypothetical casework situations.

\section{Content Analysis}

We found that the practice principles were not utilized exclusively of one another but rather that they had overlapping referrents. This indicates to us that ideas and concepts in practice do not appear as self-contained entities but rather as complex interdependent ideas that combine to form all of social work theory.

We noted that numerous times choices were made that would maintain and improve the workex-client relationship, these choices taking precedence over other choices that reflected the practice principle. Therefore, this phenomenon appears to indicate the relative importance of the worker-client relationship in social work practice. Some indication is evident that social workers consider themselves as bearers of community values and norms and consider this function to be more important than providing the client with self-determination.

In one situation, more than half of the respondents felt that, when information of a personal nature was needed, it was better 
to handle this on an individual basis than in the group. This would seem to indicate that information gathering for diagnostic purposes is not to be included in the content of the group process.

\section{Self-determination in Casework Situations}

A survey of the responses to the five hypothetical casework situations concerned with self-determination indicated that a large number of respondents were guided by the use of the practice principles relating to situations one, three, and five. However, in situations two and four, other practice principles not reflected by those particular situations were chosen more frequently as guides to the respondents' choices. Therefore, although each hypothetical situation was constructed to reflect one practice principle, the difficulty of isolating ideas in each principle was apparent. Other considerations such as the type of situations and/or using the concept of self-determination in a "pure" sense isolated from other factors affected the reasons for several of the respondents' choices.

\section{Self-determination in Group Work Situations}

The use of self-determination in the group work situations was similar to that in the casework situations in that the practice principles around which the hypothetical situations were formulated 
generally guided the respondents'reasons for choice. Again, however, some use of different practice principles was apparent, this time in situations one, two, and three. Also, some choices were based on consideration for the group decision-making process. Some respondents addressed themselves to utilizing the concept of self-determination by itself in making their respective choices.

\section{Confidentiality in Casework Situations}

Here we noted a consistent use of the practice principle as a guide for the reasons of the respondents'choices, even more so than in the self-determination casework situations. There was less use of other practice principles as guides to the respondents' choice, perhaps because there was less area of overlap in the practice principles for confidentiality than for self-determination. In practice principle five concerning the privacy of the physical facility, nine respondents indicated that they felt preservation of the worker-client relationship was more important than confidentiality.

Confidentiality in Group Work Situations

The use of confidentiality in group work was less strongly affected by the particular practice principle but was more subjected to pressures from outside factors. For example, in the 
hypothetical situation constructed around practic principle two, the respondents believed it was almost as important to preserve the relationship between worker and client (reflecting practice principle one) as to consider the question of the worker's responsibility to the community. In the group situation reflecting practice principle four, 22 respondents believed an individual casework decision was needed rather than to discuss personal information in a group setting. In the group work situation reflecting practice principle five, over half of the respondents gave reasons reflecting the practice principle. It was interesting to note, however, that for ten of the respondents, factors of expediency outweighed the need for privacy.

\section{Implications of the Study}

This study has implications for several areas of social work practice as well as suggesting avenues for further research. It has served to test two social work concepts in casework and group work practice by operationalizing the concepts through the use of practice principles. This method reduced abstract concepts to concrete practice situations that could be rated numerically. In addition, eclectic definitions of the two concepts were devised, thereby contributing: to theory development in social work practice at the direct service level. 
Because a majority of the sample lacked group work education and experience, these respondents tended to rely on casework education and experience in solving group situations. Since there appears to be a trend toward increased use of group work methods in social work practice, workers will need more education in this method.

We found that attendance at non-academic training sessions did not significantly influence workers' choices. We therefore wonder if the value of this type of training should be reassessed.

Our findings showed that workers who had more years of social work experience allowed a greater degree of self-determination and speculate that the more experienced worker is himself more secure and therefore more able to permit self-determination to the client.

Findings in regard to experience in work with groups indicate that experience is more effective than training. This has ramifications for curriculum planning which might include group work experience in the field placements of social work students. It also suggests that for those workers already employed who do not have group work experience in their background, employers should provide in-service experiences that include direct work with groups.

The study illustrated that selected knowledge from perception 
theory can be integrated and utilized for research in social work practice. Although this research group was not studying the ability of social workers to perform the role of weighters of social work situations, the problems encountered by this research group in obtaining accurate scaling of the proposed actions to hypothetical situations seem to provide evidence that there is a degree of role institutionalization in social work education and practice. It appears that the weighters' perceptual set influenced them to give maximum weight to the one choice which most reflected their judgment of good social work practice and minimum weights to all other choices, disregarding intermediate degrees of self-determination and confidentiality. This finding raises a question. Does the social worker's perceptual set inhibit his ability to shift his action oriented social work role to an objective weighting role? A future study in this area is certainly suggested.

There are other research possibilities evolving from this research. For example, a study might focus on the use of selfdetermination and confidentiality in the facilitative social work methods such as supervision, administration, and community organization. Or, utilizing the same method of operationalizing practice principles, other studies might focus on additional concepts believed to be generic to both casework and group work such as objectivity, self-awareness, empathy, etcetera. Another study 
might focus on refining the questionnaire which was developed by the current research group.

\section{Limitations of the Study}

This study is limited in several ways. The sample is geographically limited by being drawn from a single city, Portland, Oregon. The sample is greatly skewed by caseworkers, by casework training and experience, and by preference for the casework method. It is entirely possible that with a different sample different findings would be obtained.

The process of constructing similar content situations for both casework and group work under each of the practice principles and of providing choices with equal variation in the degree to which they reflect the practice principles is not without human error. The instrument itself could be refined.

In order to insure cooperation from respondents, it was necessary to restrict the size of the questionnaire and as a result some of the respondents felt they did not have enough diagnostic information. The use of a forced choice questionnaire logically. restricts the amount of information that can be obtained from the respondent. 


\section{BIBLIOGRAPHY}

1. Ackoff, Russell L. General systems theory and general systems research. In: General systems. Ann Arbor, 1963. p. $117-121$.

2. Allport, Floyd $H$. Theories of perception and the concept of structure. New York, John Wiley \& Sons, 1955. 709 p.

3. Alves, Joseph T. Confidentiality in social work. Doctoral dissertation. Washington, Catholic University of America, 1959. 268 numb. leaves.

4. Armstrong, Patricia M. et al. Constructing a tool for measuring common social work activities. Masters' thesis. Portland, Portland. State College, 1966. 81 numb. leaves.

5. Bartlett, Harriett M. Toward clarification and improvement of social work practice. Social Casework 3:3-9. April 1958.

6. Berelson, Bernard, Content analysis. In: Gardner Lindsey's Handbook of social psychology. Reading, Addison Wesley, 1959. p. 488-522.

7. Bernstein, Saul. Self-determination: king or citizen in the realm of values. Social Work 5:3-8. Jan. 1960.

8. Bertalanffy, Ludvig von. General systems theory, a critical review. In: General systems. Ann Arbor, 1962. p. $1-22$.

9. Biestek, Felix P. The principle of self-determination in social casework. Doctoral dissertation. Washington, Catholic University of America, 1951. 220 numb. leaves.

10. Bisno, Herbert. The philosophy of social work. Washington, Public Affairs Press, 1952. 143 p.

11. Bolter, Agnes et al. Toward a generic conception of human systems. Masters' thesis. Berkeley, University of California, 1962. 109 numb. leaves. 
12. Brill, Eugene et al. Toward a generic conception of social work practice. Masters' thesis. Berkeley, University of California, 1960. 80 numb. leaves.

13. Bruner, Jerome S. On perceptual readiness. Psychological Review 64:123-52.

14. Burns, Mary E. and Paul H. Glasser. Similarities and differences in casework and group work practice. Social Service Review 37:416-428. 1963.

15. Carlson, Virginia et al. Social work and general systems theory. Masters'thesis. Berkeley, University of California, 1957. 124 numb. leaves.

16. Churchill; Sallie R. The demand for competency in two social work methods, questions and challenges for education and practice. Social Work Education Reporter 14:22-23. March, 1.966.

17. Cutler, Patricia et al. Social work and general systems theory. Masters'thesis. Berkeley, University of California, 1958. 73 numb. leaves.

18. DeCristoforo, Richard L. et al. Development of a tool to measure applicability of the general systems theory to generic social work. Masters' thesis. Portland, Portland State College, 1965. 108 numb. leaves.

19. Dember, William N. The psychology of perception. New York, Henry Holt, 1960. 402 p.

20. Forgus, Ronald H. Perception. New York, McGraw-Hill, 1966. $402 \mathrm{p}$.

21. Friedlander, Walter A. Concepts and methods of social work. Englewood Cliffs, Prentice-Hall, 1958. 308 p.

22. Green, Bert F. Attitude measurement. In: Gardner Lindzey's Handbook of social psychology. Reading, Addison Wesley, 1959. p. 335-369.

23. Greenwood, Ernest. Lectures in research methodology for social welfare students. Berkeley, University of California, 1960. 
24.

Research on the clarification of casework concepts, a review and commentary on the Nolan study. Unpublished paper prepared for the coloquim of the School of Social Welfare. Berkeley, University of California, 1963.

25. Hamilton, Gordon. Theory and practice of social casework. New York, Columbia University Press, 1951. 328 p.

26. Hearn, Gordon. Theory building in social work. Toronto, University of Toronto Press, 1958. $88 \mathrm{p}$.

27. Hollis, Florence. Casework, a psychosocial therapy. New York, Random House, 1964. 300 p.

28. Kendall, Katherine A. New dimensions in casework and group work practice: implications for professional education. Social Work 4:49-56. Oct. 1959.

29. Konopka, Gisela. Social group work, a helping process. Englewood Cliffs, Prentice-Hall, 1963. 307 p.

30. McBroom, Elizabeth. Individual, group, and community in the behavior sequence. Journal of Education for Social Work $1: 27-34$. Fall 1956.

31. National Association of Social Workers. Use of judgments as data in social work research. New York, $1959.105 \mathrm{p}$.

32. New York School of Social Work. Social casework, an outline for teaching. eds. Mary Antoinette Cannon and Phillip Klien. New York, Columbia University Press, 1933. 626 p.

33. Perlman, Helen Harris. Self-determination, reality or illusion. Social Service Review 39:410-421. 1.965.

34. Social casework, a problem solving. process. Chicago, University of Chicago Press, 1957. 268 p.

35. Powdermaker, Florence and Jerome Frank. Group psychotherapy. Cambridge, Harvard University Press, 1953. 615 p.

36. Richmond, Mary. What is social casework? New York, Russell Sage Foundation, 1922. 268 p. 
37. Ruch, Floyd L. Psychology and life. 5th ed. Chicago, Scott Foresman, 1958. 624 p.

38. Ruch, Floyd L. et al. Campus outlines: intermediate statistics on psychology and education. Columbia, Lucas Brothers, 1958. $133 \mathrm{p}$.

39. Seltiz, Claire et al. Research methods in social relations. New York, Holt, Rinehard and Winston, 1962. 622 p.

40. Siegel, Sidney. Nonparametric statistics for the behavioral sciences. New York, McGraw-Hill, 1956. 312 p.

41. Slavson, S. R. An introduction to group therapy. Rev. ed. New York, International Universities Press, 1954. 352 p.

42. Solley, Charles M. and Gardner Murphy. Development of the perceptual world. New York, Basic Books, 1960. 353 p.

43. Trecker, Harleigh B. Social group work, principles and practices. Rev. ed. New York, Association Press, 1955. $442 \mathrm{p}$.

44. Weingarten, Victor. Breaking the barriers of confidentiality. Child Welfare 37:1-6. April 1958.

45. Whitaker, Dorothy S. and Morton A. Lieberman. Psychotherapy through the group process. New York, Atherton Press, 1964. 293 p.

46. Wilson, Gertrude. Social group work, trends and developments. Social Work 1:66-75. October 1956.

47. Wilson, Gertrude and Gladys Ryland. Social group work practice. Cambridge, Riverside Press, 1949. 687 p. 


\section{APPENDIX}

1. Instructions to Weighters

2. Face Sheet

3. Instructions to Respondents

4. Questionnaire

5. Telephone Request to Prospective Respondents. 
INSTRUCTIONS FOR WEIGHTERS

The following questionnaire has been prepared by a group of students who are in their second year of study toward a Master of Social Work degree. The data gained from this questionnaire will be used as the basis for a group thesis.

The questionnaire contains twenty hypothetical situations that exemplify the concepts of self-det ermination and confidentiality in social casework and social group work practice. Following each situation are four different actions the worker could take, each action reflecting a different degree of self-determination or confidentiality that could be utilized by the worker. We are asking that you rank each of the four choices on a scale of from 1-10 and assign a higher numerical rating to those choices that, in your opinion, reflect a greater degree of either self-determination or confidentiality.

In order to make the scale a valid instrument, it will be necessary to have the score for all four choices add up to the sum of 10 . You may give any numerical rating that you choose to any of the four actions so long as the sum stays within this limit. Your answer should not necessarily reflect what you would do if you were the worker in question.

To provide you with a frame of reference for defining self- 
determination and confidentiality, we are asking you to utilize the following definitions of the two concepts as a basis for ranking each of the four workers' actions. In other words, whether you consider one action more self-determining or confidential than another will be decided within the context of the definition provided. Our definition for self-determination is as follows:

Self-determination in social work practice is the worker's conscious recognition of the right of the client to direct his own life, to pursue his own goals, to meet his own needs and to determine how these needs should be met as they are compatible with the realities of his diagnosed capacities, in relation to the rights of other persons and within the context of society's limitations.

Our definition for confidentiality is as follows:

Confidentiality in social work practice is the restriction of personal information about the client by the social worker based on the respect for the client's right to privacy; or the ethical and purposeful release of information about the client by the social worker in order to facilitate explicit treatment goals.

We wish to express our appreciation to you for your assistance in this research project and we will welcome any comments you wish to make on the back of the pages. 
Number

FACE SHEET

Date

1. How many years paid social work experience have you had?

2. Where are you currently employed?

3. If you are not currently employed, where was your most recent employment?

4. What is/was your position at your place of current or most recent employment?

5. Have you had experience of a treatment nature in working with groups of clients?_If so, how much (in years)?

6. Have you had experience of a treatment nature in working with individual clients? If so, how much (in years)?

7. Have you had graduate education in casework? If so, how much (in years)?

8. Have you had graduate education in group work? If so, how much (in years)?

9. Have you had any other type of training in casework? If so, how much (in years)? What was the nature of this training?

10. Have you had any other type of training in group work? If so, how much (in years)? What was the nature of this training?

11. Do you prefer to work with clients in a casework or group work relationship? Please circle your preference.

12. Which of the following social work degrees have you completed? Please circle. Masters Third Year Doctorate 
INSTRUCTIONS

The following questionnaire has been prepared by a group of students who are in the second year of study toward a Master of Social Work degree. This group is engaged in a research project to determine how social workers use the concepts of confidentiality and self-determination in actual practice. The data will be used as the basis for a group thesis.

The questionnaire contains twenty hypothetical situations which might occur in social work practice. Each situation is followed by four possible actions that might be taken by a social worker who is confronted with the situation.

We are asking that you imagine yourself as the social worker in each situation and that you choose only one of the four possible actions as the one that you would take. If you feel that none of the choices are appropriate or that a better choice exists but is not listed, please choose one of the four listed that you would most likely do and assume that you are in a position which limits your choice to one of these four. Please write the reason for each choice in the space provided.

We would appreciate your working on this questionnaire individually as other persons known to you may also be included in the sample. We wish to express our appreciation to you for 
your assistance in this research project and we will welcome any comments you wish to make on the back of the pages. 
QUESTIONNAIRE Number

\section{WORKER'S USE OF SELF-DETERMINATION}

You are a worker in a family service agency where your assignment is to provide short-term counselling to an 18 year old girl considering marriage to a college student. Choose one of the following actions you would most likely take.

Advise the girl not to marry because she would have to work to support the family as long as the boy remains in school. In addition, she will be able to choose a husband more wisely when she is a little older.

Tell the girl some of the difficulties you forsee in an early marriage but it is up to her to make her own decision. She can make marriage a success if she is willing to work at it.

$\square$ Discuss with the girl both the advantages and disadvantages of early marriage in general and some of the pros and cons of her particular situation but refrain from making a recommendation.

Suggest the girl "go steady" for at least a year and then reconsider whether she wishes to marry.

What is your reason for the above choice?

You are a worker in a public welfare agency assigned to a family consisting of a mother and young children. The mother prefers to live in a house with neither water nor electricity, which does not provide protection from the weather. Although entitled to an increased amount of money to cover the cost of better housing, the mother claims their way of life to be emotionally healthy. Choose one of the following actions you would most likely take.

Locate other housing for the family.

Continue to provide financial aid to the family and refrain from discussing the housing situation further.

Suggest the mother look for other housing that more nearly meets the community standard for decency and health.

Infer that unless a change is made, there may be legal action concerning the children remaining in the home.

What is your reason for the above choice? 
Number

\section{WORKER'S USE OF SELF-DETERMINATION}

You are a worker who meets weekly with a group of ADC mothers to discuss some of their problems. In the course of a meeting, the mothers express concern regarding supervision of their adolescent children: Choose one of the following actions you would most likely take.

Advise them to read a book on Living. With Your Teenager which will help them understand how children feel and act.

Tell them they should insist their children report where they are going, whom they will be with, and set a definite time for them to be home.

Suggest that some of them have experience with teenagers which they might like to share so as to be helpful to others who have questions.

Suggest they discuss further some specific problems such as dating, staying out late, drinking.

What is your reason for the above choice?

You are a worker in a home for unwed mothers. In a group meeting you encounter the problem of a new girl being subjected to group criticism because she does not do her share of the work. Choose one of the following actions you would most likely take.

Praise the group for its help to new girls and invite their suggestions as to how the orientation process might be made more pleasant for all concerned.

Refrain from comment, believing that the other girls will soon accept the newcomer as she becomes more conforming.

Intercede and tell the group to quit hazing the newcomer.

Remind the group how it was for them when they first came and suggest they give the new girl time to learn how to do things.

What is your reason for the above choice? 
Number

\section{WORKER'S USE OF SELF-DETERMINATION}

You are a worker in a public welfare agency. An aged client who lives alone in a rural area is reported by neighbors to have fainting spells. They believe he should be taken to an old people's home. However, the client is sentimentally attached to his home where he has lived for many years. Choose one of the following actions you would most likely take.

Make arrangements for him to visit several homes for elder... ly persons.

Tell him the names of several homes for the elderly and insist he make a decision as to which home he will go.

Point out various possibilities open to him in sheltered living situations.

Respect the client's decision to stay in his own home and suggest housekeeping services.

What is your reason for the above choice?

You are a worker who takes a teenage girl from a foster home on a shopping trip for clothing. The girl likes and wishes to buy a dress that you consider too short and close-fitting for best appearance. Choose one of the following actions you would most likely take. take.

Allow the teenager to buy the dress with the stipulation that she must let the hem down.

Tell the teenager she cannot buy the dress.

Allow the teenager to buy the dress as it is without making any. stipulation for change.

Ask the salesgirl to find the same dress in a size larger.

What is your reason for the above choice? 
Number

\section{WORKER'S USE OF SELF-DETERMINATION}

You are a worker assigned to a girls' club which meets at a settlement house. Members are thirteen and fourteen years old. They are planning a party and want to invite boys and wear their "grubbies". (informal clothing) Choose one of the following actions you would most likely take.

Suggest they wear dressier clothing since boys behave in a more gentlemanly fashion when dressed up.

Remind them of the last party when some of the boys tore down decorations and were in other ways not well-mannered.

Suggest they should not ask boys because they are too young to be dating.

Refrain from making any suggestions to the group as to guests or dress.

What is your reason for the above choice?

You are a child welfare worker who is approached by a fourteen year old boy who requests that you place him in a different foster home as he complains his present foster parents are too strict and do not understand him. The foster parents admit that the boy is rebelling against family "rules", but are willing to have him remain in their home. Choose one of the following actions you would most likely take.

Have a talk with the boy, advising him to straighten up and start following family rules.

Arrange some trial visits to foster homes for the boy to decide which home he wants.

Attempt to dissuade the boy from the plan of going to another foster home, and advise him to make a concerted effort to get along for a month's time. If this does not work out, plan to discuss the problem with him again.

Arrange for the boy to meet with you to consider why he is not getting along before attempting to find another foster home for him.

What is your reason for the above choice? 
Number

\section{WORKER'S USE OF SELF-DETERMINATION}

You are a social worker with a group of early adolescent boys who hold activity club meetings in a neighborhood house. The Board of Directors has complained that damage to the building has resulted from overly-rough play of the boys. Choose one of the following actions you would most likely take.

Limit their activities to certain sports and insist that there be no horseplay on the side.

Tell them that any more property damage caused by them will result in their no longer being able to use the building.

Request that the boys be more respectful of the property.

Discuss the problem with the group, inviting their ideas about how they could prevent further damage.

What is your reason for the above choice?

You are a worker in a correctional institution who meets with a group of girls aged 16 and 17 . They are discussing their forthcoming return to public high schools, are poorly motivated academically, and would like to be excused from further attendance. Oregon compulsory school attendance law states that all children must attend school until they are 18 or graduate from high school unless they are formally excused from school through action of their local school board initiated by their legal guardian. Choose one of the following actions you would most likely take.

Tell them it is highly desirable they remain in school for they cannot get good jobs without more education.

Agree to talk with school officials about the possibility that some of them, depending on their scholastic ability, may be excused from further school attendance.

Say that all of them must at least try public school. If they fail, their request may be reconsidered.

Advise them they must comply with the law.

What is your reason for the above choice? 
Number

\section{WORKER'S USE OF CONFIDENTIALITY}

You are a worker in a family counselling agency where a distraught client comes for help with her marital problems. During one of the early interviews, the client inadvertently reveals the existence of an illegitimate child she has since placed for adoption. Neither her husband nor her friends know about this child and she is admittedly reluctant to discuss the matter further with you. Choose one of the following actions you would most likely take.

Inform the client the information will be shared with others within the agency and with other agencies in order to better help her with her problems.

Inform the client the information may be shared with others within the agency in order to facilitate treatment of her problems.

Inform the client this information will be shared with other legitimate persons who have an honest interest in her welfare.

$\square$ Inform the client personal information will be revealed to no one without her prior consent.

What is your reas on for the above choice?

You are a worker in a family service agency who has just formed a new therapy group. Meetings are to be held each Thursday at 10:00 $A$. M. in the agency conference room. On the afternoon before the first meeting, you find a meeting of the agency board of directors has been scheduled for the conference room at the same time as your meeting. The board of directors cannot be moved. There is no other room in the agency large enough for your group except the agency lounge which will be unoccupied except for an occasional person crossing it as a shortcut to other areas. Choose one of the following actions you would most likely take.

Since the day promises to be warm, hold your meeting on the patio beside the building.

Schedule your meeting for one corner of the lounge and use a portable screen to partially isolate the area.

Reschedule your meeting for the afternoon when the conference room will be available.

Schedule your meeting for one corner of the lounge and post notices of the meeting outside the lounge, realizing this will not guarantee that no one will come through.

What is your reason for the above choice? 
Number

\section{WORKER'S USE OF CONFIDENTIALITY}

You are a worker who has established contact with a gang of teenage boys and are holding regular meetings in a local community center. During one of these meetings, a member reveals that the gang has been involved in a series of recent store break-ins in the neighborhood. This information is not known to the local police and if they becomeaware of it, the boys may incur a severe penalty. Choose one of the following actions you would most likely take.

Encourage the boys, during the meeting, to reveal their infractions to the police and volunteer to accompany them to the police station to asist in any way posible.

Inform the police about this situation as soon as the meeting is over.

Tell the group they have a week to correct the situation. If they do not, you may have to turn them over to the police.

Take no action unless the police should question you concerning this situation, then be cooperative.

What is your reason for the above choice?

You are a worker who is meeting the first time with a group of mothers whose children are having problems in school. They are hesitant to discuss personal yet pertinent information about their family situations. Choose one of the following actions you would most likely take.

Inform the group it is alright if they discuss what is said in the group with their spouses.

Inform the group they may discuss the content of the group meeting with whomever they want since most parents have similar problems with their children and they would understand.

Inform the group they can feel free to discuss personal matters during their meetings for what is said in the meetings must remain within the group setting.

Inform the group they may discuss what is said in the meetings with spouses and friends who may help with their advice.

What is your reason for the above choice? 
Number

\section{WORKER'S USE OF CONFIDENTIALITY}

You are a worker who finds it necessary to refer your client to another agency where more specialized treatment for his problem is available. However, you are not sure to what degree the confidentiality of the information concerning your client will be respected by the receiving agency. Choose one of the following actions you would most likely take.

Refer your client to the agency and forward all pertinent information to their staff.

$\square$ Contact the agency to determine how the personal information about your client will be handled before making your decision of referral.

Withhold personal information about your client.

Mark all personal information with a confidential stamp and forward it to the agency.

What is your reason for the above choice?

You are a worker in a county welfare department working with a group of ADC mothers. During a group discussion, several of the members mention having participated in group marriage counselling. at mental health clinics in other cities. This information was previously unknown to your agency and you would like to have summaries of clinic contacts with these women. Choose one of the following actions you would most likely take.

Convene a subgroup of those with the prior marriage conselling experience and ask their permission to write for the summaries.

Write for the summaries and discuss their implications with the clients later if pertinent to treatment.

$\square$ Privately ask each client if you may try to obtain a summary.

Ask the group to decide if summaries should be obtained about the members concerned.

What is your reason for the above choice? 
Number

\section{WORKER'S USE OF CONFIDENTIALITY}

You are a worker in a family service agency who has just completed an interview with a client who is having problems with her marriage. As you review your notes, you discover this client has been known to a particular state mental hospital. Choose one of the following actions you would most likely take.

Wait a week until the next interview and then ask the client if you may wirite the hospital for information about her.

Phone the client to ask if you may write the hospital for information about her.

$\square$ Send the client a letter telling her you are witing the hospital for information about her.

Write the hospital requesting information but do not mention this to the client.

What is your reason for the above choice?

You are a worker in a juvenile correctional institution who has been working with a group of adolescents, all of whom have been released within the past thirty days. You are visited by a worker froma social agency who is now working with this group. He requests all the information you have about his clients. Choose one of the following actions you would most likely take.

Give the worker access to all the information in your files.

Give the worker access to the files about members of the group after being assured all information will be kept confidential.

$\square$ Give the worker access to the information if he has a release signed by all the group members.

Tell him your files are confidential and you can give him no information about the group members.

What is your reason for the above choice? 


\section{WORKER'S USE OF CONFIDENTIALITY}

You are a worker in a welfare agency. During a regularly scheduled visit with you, a client reveals she recently overheard her brother and a friend planning a bank robbery. The client cannot decide whether to inform the police or to do nothing and run the risk this crime will be committed which will endanger both her brother and the community. Choose one of the following actions you would most likely take.

Keep this information private and within the confines of the worker-client relationship.

Take no action unless the police should question you concerning this situation and then be cooperative.

$\square$ After the client leaves the interview, pick up the telephone and notify the police of this situation.

Try to convince the client she must notify the police of this situation but if you are unsuccessful, notify them yourself.

What is your reason for the above choice?

You are a worker in a settlement house. One of your clients is a neighborhood gang leader who has been referred by the school. After several interviews, he is still quite resistant. You know he has called other boys "sissy" for coming into the settlement house. One afternoon, while a basketball game is in progress, you notice this boy covertly looking in through a window toward your office which opens off the basketball floor. You are aware he has family problems and may need someone to talk to. Choose one of the following actions you would most likely take.

Take him to a nearby coffee shop and talk to him there.

Go outside, talk to him briefly and invite him to return after the other boys have gone.

Gently maneuver the boy through the gymnasium and into your office for a private chat.

$\square \quad$ Call out and invite him in.

What is your reason for the above choice? 
TELEPHONE MESSAGE TO PROSPECTIVE RESPONDENTS

1. Identify yourself by name as a student from PSC SSW.

2. Member of a research project for MSW and have drawn random sample from NASW directory. Your name was included in the sample.

3. We would appreciate your taking the time to respond to a questionnaire. The time for pre-test group was between 35 and 65 minutes.

4. If agreed, then will deliver to your home or office. 